\title{
Temperature and relative humidity influence the microbial and physicochemical characteristics of Camembert-type cheese ripening
}

\author{
M.-N. Leclercq-Perlat, ${ }^{1}$ M. Sicard, I. C. Trelea, D. Picque, and G. Corrieu \\ UMR Génie et Microbiologie des Procédés Alimentaires (GMPA), INRA 782, BP1, avenue Lucien Brétignières, \\ F-78 850 Thiverval-Grignon, France
}

\begin{abstract}
To evaluate the effects of temperature and relative humidity $(\mathrm{RH})$ on microbial and biochemical ripening kinetics, Camembert-type cheeses were prepared from pasteurized milk seeded with Kluyveromyces marxianus, Geotrichum candidum, Penicillium camemberti, and Brevibacterium aurantiacum. Microorganism growth and biochemical changes were studied under different ripening temperatures $\left(8,12\right.$, and $\left.16^{\circ} \mathrm{C}\right)$ and $\mathrm{RH}(88,92$, and $98 \%)$. The central point runs $\left(12^{\circ} \mathrm{C}, 92 \% \mathrm{RH}\right)$ were both reproducible and repeatable, and for each microbial and biochemical parameter, 2 kinetic descriptors were defined. Temperature had significant effects on the growth of both $K$. marxianus and G. candidum, whereas $\mathrm{RH}$ did not affect it. Regardless of the temperature, at $98 \% \mathrm{RH}$ the specific growth rate of $P$. camemberti spores was significantly higher [between $2\left(8^{\circ} \mathrm{C}\right)$ and 106 times $\left(16^{\circ} \mathrm{C}\right)$ higher]. However, at $16^{\circ} \mathrm{C}$, the appearance of the rind was no longer suitable because mycelia were damaged. Brevibacterium aurantiacum growth depended on both temperature and RH. At $8^{\circ} \mathrm{C}$ under $88 \% \mathrm{RH}$, its growth was restricted $\left(1.3 \times 10^{7} \mathrm{cfu} / \mathrm{g}\right)$, whereas at $16^{\circ} \mathrm{C}$ and $98 \% \mathrm{RH}$, its growth was favored, reaching $7.9 \times 10^{9} \mathrm{cfu} / \mathrm{g}$, but the rind had a dark brown color after d 20. Temperature had a significant effect on carbon substrate consumption rates in the core as well as in the rind. In the rind, when temperature was $16^{\circ} \mathrm{C}$ rather than $8^{\circ} \mathrm{C}$, the lactate consumption rate was approximately 2.9 times higher under $88 \% \mathrm{RH}$. Whatever the $\mathrm{RH}$, temperature significantly affected the increase in rind $\mathrm{pH}$ (from 4.6 to $7.7 \pm 0.2$ ). At $8^{\circ} \mathrm{C}$, an increase in rind $\mathrm{pH}$ was observed between d 6 and 9, whereas at $16^{\circ} \mathrm{C}$, it was between $\mathrm{d} 2$ and 3 . Temperature and $\mathrm{RH}$ affected the increasing rate of the underrind thickness: at $16^{\circ} \mathrm{C}$, half of the cheese thickness appeared ripened on d 14 (wrapping day). However, at 98\% RH, the underrind was runny. In conclusion, some descriptors,
\end{abstract}

Received January 23, 2012.

Accepted April 13, 2012.

${ }^{1}$ Corresponding author: perlat@grignon.inra.fr such as yeast growth and the $\mathrm{pH}$ in the rind, depended solely on temperature. However, our findings highlight the fact that the interactions between temperature and RH played a role in $P$. camemberti sporulation, B. aurantiacum growth, carbon substrate consumption rates, and the thickening of the cheese underrind. Moreover, the best ripening conditions to achieve an optimum between microorganism growth and biochemical kinetics were $13^{\circ} \mathrm{C}$ and $94 \% \mathrm{RH}$.

Key words: temperature, relative humidity, microbial growth, biochemical evolution

\section{INTRODUCTION}

Many environmental parameters, mainly temperature, relative humidity $(\mathbf{R H})$, and gaseous atmosphere composition of the ripening chambers, affect the ripening of surface mold-ripened soft cheeses (Choisy et al., 2000; Ramet, 2000). In modern cheese plants, to achieve better control of the quality, ripening starters are typically used to supply the microorganisms. The ripening starter is generally composed of yeasts (mainly Kluyveromyces spp. and Geotrichum candidum), Penicillium camemberti, and surface bacteria. In the case of Camembert-type cheeses throughout the entire ripening process, the evolution in microbial and biochemical characteristics carried out a under constant, controlled temperature $\left(12 \pm 1^{\circ} \mathrm{C}\right)$ and $\mathrm{RH}(93 \pm 1 \%)$ has already been investigated (Leclercq-Perlat et al., 2004, 2006).

The effects of ripening conditions on cheese characteristics have been studied for numerous types of cheeses. For goat cheese, Malcata et al. (1995) showed the effects of ripening temperature and $\mathrm{RH}$ on proteolysis and lipolysis. For a soft smear cheese, Bonaïti et al. (2004) pointed out the influence of temperature on the ripening dynamics, but these authors did not show the effect of $\mathrm{RH}$ on the microbial and biochemical parameters of ripening, except in the case of water mass loss. For a hard cheese (Reggianito Argentino), Sihufe et al. (2007, 2010 a,b) showed the influence of ripening temperature on proteolysis and lipolysis, and they were able to estimate the optimal ripening time. For an uncooked pressed cheese, Callon et al. (2011) showed 
the importance of temperature and $\mathrm{RH}$ in controlling the growth of Lactobacillus and their inhibition activities on Listeria monocytogenes. To our knowledge, little work has focused on the influence of temperature and $\mathrm{RH}$ on the cheese-ripening qualities of Camembert-type cheeses.

According to Hemme and Richard (1986), the growth of G. candidum, P. camemberti, and Brevibacterium aurantiacum on the surface of Camembert-type cheeses is an essential prerequisite for the development of the aroma, flavor, color, and texture. Consequently, the environmental factors (e.g., the temperature and hygrometry in the ripening chamber) that play a role in microorganism growth also play a role in microbial development and enzymatic reactions (van den Tempel and Jakobsen, 2000). Indeed, increasing the temperature by 3 to $4^{\circ} \mathrm{C}$ is the easiest and most economically feasible strategy to accelerate ripening (Nunez et al., 1991). However, in the case of soft mold cheeses, important enzymatic activities are triggered by the prospering surface flora. When the temperature is increased, so is the level of these activities, largely modifying cheese qualities such as texture and taste (Reps, 1993; Ramet, 2000). Throughout ripening, RH affects both the total water content and the water activity on the cheese surface (Gripon, 1993; Reps, 1993; Hardy et al., 2000; Simal et al., 2001). A decrease in RH from 98 to $95 \%$ has been shown to increase cheese water losses by 2.5 times (Mirade et al., 2004). This is, in part, affected by airflow rate, which was also shown to have an effect on water evaporation (Von Weissenfluh and Puhan, 1987). Weight losses have been known to increase by 6 times when air velocity changes from 0 to $0.5 \mathrm{~m} / \mathrm{s}$ (Mirade et al., 2004). Airflow rate also changes the atmospheric composition, which acts on ripening phenomena. Chamber hygrometry varies from 90 to $95 \%$ for soft mold cheeses (Lesage-Meessen and Cahagnier, 1998). Consequently, a part of the water in the cheese evaporates into the atmosphere, leading to a decrease in cheese mass and water content (Hardy et al., 2000). This water loss is related to different cheese parameters (initial water quantity, specific surface, bound water quantity, and surface density; Reps, 1993; Hardy et al., $2000)$. If the $\mathrm{RH}$ is higher than $95 \%, P$. camemberti mycelium development is poor (Lenoir et al., 1985), Moreover, if the RH value is lower than $90 \%$, water loss is excessive and the cheese is therefore too dry. Regardless of the soft cheese undergoing ripening, the total water weight loss throughout ripening must not vary by any more than 10 to $15 \%$ of the initial weight. Hygrometry also plays a role in restricting the growth of undesirable microorganisms, but it must do so without inhibiting the growth of the ripening microorganisms (Lesage-
Meessen and Cahagnier, 1998). Bonaïti et al. (2004) defined the best ripening conditions of microbial and biochemical characteristics in terms of temperature and $\mathrm{RH}\left(13^{\circ} \mathrm{C}\right.$ and $95 \pm 1 \%$, respectively) of a soft smear cheese seeded with a very simple starter (Debaryomyces hansenii and B. aurantiacum). However, little research has been published on the influences of temperature and $\mathrm{RH}$ in Camembert-type cheeses undergoing ripening, which, in part, explains why the regulation of these conditions remains fixed in ripening chambers at plants producing the real cheeses.

The aim of this study was to evaluate the effects of ripening chamber temperature and $\mathrm{RH}$ on microbial developments, biochemical changes, and the corresponding kinetics of Camembert-type cheeses throughout the ripening process (in the chamber from d 0 to 14 and under wrapping from d 14 to 40).

\section{MATERIALS AND METHODS}

\section{Biological Material}

Kluyveromyces marxianus [GMPA collection, 44 8 ), G. candidum (strain D, Cargill, La Ferté-sous-Jouarre, France), P. camemberti (strain R, Cargill), and B. aurantiacum (ATCC 9175; ATCC standard, American Type Culture Collection, Manassas, VA) were the given ripening cultures. Flora Danica lyophilisat (CHN11 for 1,000 L of milk, Chr. Hansen, Saint-Germain-lesArpajon, France) was the given mesophilic lactic acid bacteria (LAB) culture. Before each cheese-making run, $2.5 \mathrm{~g}$ of this LAB was mixed in $1.5 \mathrm{~L}$ of sterile $\left(115^{\circ} \mathrm{C}, 10 \mathrm{~min}\right)$ skim milk and then cultured at $30^{\circ} \mathrm{C}$ for $16 \mathrm{~h}$ without stirring. The preparations of ripening strains and their numeration were carried out as described previously by Leclercq-Perlat et al. (2004).

\section{Cheese Making}

The cheeses were prepared on a pilot scale under aseptic conditions in a sterilized $3-\mathrm{m}^{3}$ chamber, in which the coagulation, cutting, draining, and shaping of the curds were carried out. The chamber and all the nonautoclavable pieces of equipment were cleaned and sterilized as described previously by Leclercq-Perlat et al. (2004). The temperature of the cheese-making chamber was maintained at $28 \pm 1^{\circ} \mathrm{C}$.

For each cheese-making run, $200 \mathrm{~L}$ of milk was used to make 100 Camembert-type cheeses. The raw milk and the skim milk were obtained from the AgroParisTech experimental farm (Thiverval-Grignon, France). It was standardized at $29 \mathrm{~g} / \mathrm{L}$ of fat by mixing skim and full-cream milk and at $35 \mathrm{~g} / \mathrm{L}$ of total protein 
matter by adding milk protein powder (852, Ingredia, Arras, France). After mixing, the milk was pasteurized (2 min $30 \mathrm{~s}$ at $77 \pm 1^{\circ} \mathrm{C}$ ) and cooled to the incubation temperature $\left(34 \pm 1^{\circ} \mathrm{C}\right)$. The $\mathrm{pH}$ of the milk varied between 6.5 and 6.6. After pouring the first liters of milk into the coagulation tank, that milk was inoculated with the LAB starter $(1.5 \%, \mathrm{vol} / \mathrm{vol})$ and the ripening starters. After the tank was filled with the remaining pasteurized milk, the concentrations of $K$. marxianus, G. candidum, P. camemberti, and B. aurantiacum were $4 \times 10^{3} \mathrm{cfu} / \mathrm{mL}, 80 \mathrm{cfu} / \mathrm{mL}, 8 \times 10^{3}$ spores $/ \mathrm{mL}$, and 2 $\times 10^{4} \mathrm{cfu} / \mathrm{mL}$, respectively. Because of the LAB activity, the milk $\mathrm{pH}$ reached 6.3 after 80 to $110 \mathrm{~min}$. The rennet $(520 \mathrm{mg} / \mathrm{L}$ of chymosin, Chr. Hansen) was then added $(20 \mathrm{~mL} / 100 \mathrm{~L})$. Coagulation took $20 \mathrm{~min}$, and the hardening that followed took $40 \mathrm{~min}$. The curd was then cut into 2 -cm cubes. After another $40 \mathrm{~min}$, roughly $80 \mathrm{~L}$ of whey was drained to obtain an average cheese DM between 40 and $42 \%$. The curd was then shaped in polyurethane molds (diameter $107 \mathrm{~mm}$, height $77 \mathrm{~mm}$ ), producing cheeses weighing $300 \pm 20 \mathrm{~g}$. After the end of molding, the molds were turned after $30 \mathrm{~min}, 5 \mathrm{~h}$, and $19 \mathrm{~h}$. Moreover, $3 \mathrm{~h}$ after the end of molding, the temperature of the cheese-making chamber was reduced to $21 \pm 1^{\circ} \mathrm{C}$. Twenty hours after molding, the cheeses were turned out, and $24 \mathrm{~h}$ after the end of molding, the cheeses were pickled for $25 \mathrm{~min}$ in sterile $(2 \times 30 \mathrm{~min}$ at $\left.120^{\circ} \mathrm{C}\right)$ brine $(330 \mathrm{~g}$ of $\mathrm{NaCl} / \mathrm{L}$ at $\mathrm{pH} 5.5)$ at $14 \pm 1^{\circ} \mathrm{C}$. Then, after $1 \mathrm{~h}$ of drying to eliminate the excess brine, they were transferred to the ripening chambers, which had been sterilized beforehand with peracetic acid. This was designated the initial ripening time (d 0 ).

For each cheese-making run, between $\mathrm{d} 0$ and 1 , the cheeses were maintained at $12^{\circ} \mathrm{C}$ and $85 \% \mathrm{RH}$ to dry the surfaces of the cheeses. Between d 1 and 13, they were then kept at a given controlled temperature $(8 \pm$ $1,12 \pm 1$, or $16 \pm 1^{\circ} \mathrm{C}$ ) and a given controlled $\mathrm{RH}(88$ $\pm 1,92 \pm 1$, or $98 \pm 2 \%$ ), with the same periodically renewed atmosphere. To that end, on $\mathrm{d} 0$, the ripening chamber, which contained air $\left(\mathrm{CO}_{2}=0 \%\right)$, was sealed. Given that during respiration the $\mathrm{CO}_{2}$ concentration increases (in our case, when the $\mathrm{CO}_{2}$ concentration reached $0.5 \%$ ), it was automatically decreased to $0.1 \%$ by injecting humid sterile air $\left(21 \% \mathrm{O}_{2}, 79 \% \mathrm{~N}_{2}\right)$ as described by Picque et al. (2006). On d 5, the cheeses were turned. On d 13, regardless of the given temperature and $\mathrm{RH}$, the temperature and $\mathrm{RH}$ were regulated at $12^{\circ} \mathrm{C}$ and $85 \%$ to dry the cheese surface. On d 14 , they were wrapped in a reference film (Amcor Flexibles, Barbézieux, France) and stored to continue ripening at $4^{\circ} \mathrm{C}$ until $\mathrm{d} 40$. Between $\mathrm{d} 1$ and 14 , a cheese was removed and analyzed on a daily basis, and between $\mathrm{d}$ 14 and 40, this was done on a weekly basis.

\section{Analyses of the Cheeses}

The rind (2 $\mathrm{mm}$ in height on all cheese surfaces) and core of each cheese were separated and analyzed as described previously by Leclercq-Perlat et al. (2004). Because only $K$. marxianus and $G$. candidum grow in the core and reach concentrations 500 to 1,000 times lower than the ones in the rind (Leclercq-Perlat et al., 2004, 2006), the viable cell counts of ripening strains were measured only in the cheese rind. These counts were carried out as described previously by Leclercq-Perlat et al. (2004). The $\mathrm{pH}$ of the rind as well as lactose and lactate concentrations in both the rind and the core were measured as indicated previously (LeclercqPerlat et al., 2004, 2006). For each cheese sample, the underrind thickness of the cheese was measured using the first $14 \mathrm{~mm}$ at 6 points per face. The arithmetic average of these 12 measurements was then calculated. For each run, 20 cheeses were weighed on d 1 and 14 to an accuracy of $0.01 \mathrm{~g}$ to determine the average water mass loss.

\section{Experimental Design}

The analyses were carried out using a 2-factor, 3-level complete factorial experimental design $\left(3^{2}\right)$. The 2 factors were temperature and $\mathrm{RH}$, and the 3 levels of each factor were 8,12 , and $16^{\circ} \mathrm{C}$ for temperature and 88,92 , and $98 \%$ for RH. These levels were chosen according to the range of temperatures and $\mathrm{RH}$ used at the plant in the ripening of Camembert cheese. The 9 combinations of temperature and $\mathrm{RH}$ are shown in Tables 1, 2, and 3 (left part). Because the experiment took place over a lengthy period, only the runs corresponding to the central point of the experimental design $\left(12^{\circ} \mathrm{C}, 92 \%\right.$ $\mathrm{RH}$ ) were quintupled (runs 6 to 10). The runs under $8^{\circ} \mathrm{C}$ and $98 \% \mathrm{RH}$ (runs 3 and 4 ) and those under $16^{\circ} \mathrm{C}$ and $88 \% \mathrm{RH}$ (runs 12 and 13) were simply duplicated. The remaining runs were completed only once.

\section{Statistical Analyses}

For the runs carried out under the same conditions (runs 3 and 4, runs 6 to 10 , and runs 12 and 13), cell counts, lactose and lactate concentrations, $\mathrm{pH}$ of the rind, and water mass loss were compared using a 2-factor (run and time) ANOVA with Statistica software 6.1 (Statsoft, Maisons-Alfort, France). The hypotheses examined were the equality of the runs and the absence of false interpretation. To control the equality of runs, this test was significant for the risk $\alpha\left\{\left[\alpha=1-\mathrm{p}\left(\mathrm{F}_{\text {obs }}\right.\right.\right.$ $\left.\left.\left.<\mathrm{F}_{\text {crit }}\right)\right] \leq 0.01\right\}$. To evaluate the risk of false interpretation, the test power $(1-\beta)$ was determined accord- 
Table 1. Presentation of the 2-factor, 3-level complete factorial experimental design ( $3^{2}$; left), and values of kinetic descriptors of Kluyveromyces marxianus (KM), Geotrichum candidum (GC), Brevibacterium aurantiacum (BA), and Penicillium camemberti (PC) for each temperature $\left(\theta\right.$, $\left.{ }^{\circ} \mathrm{C}\right)$ and relative humidity $(\mathrm{RH}, \%)$ during Camembert-type cheese ripening in the chamber (right)

\begin{tabular}{|c|c|c|c|c|c|c|c|c|c|c|c|}
\hline \multirow[b]{3}{*}{ Run no. } & & & \multicolumn{3}{|c|}{ K. marxianus } & \multirow{2}{*}{\multicolumn{2}{|c|}{$\begin{array}{l}\text { G. candidum, } \\
\text { growth phase }\end{array}$}} & \multirow{2}{*}{\multicolumn{2}{|c|}{$\begin{array}{l}\text { B. aurantiacum, } \\
\text { first growth phase }\end{array}$}} & \multirow{2}{*}{\multicolumn{2}{|c|}{$\begin{array}{c}\text { P. camemberti, } \\
\text { sporulation phase }\end{array}$}} \\
\hline & \multicolumn{2}{|c|}{$\begin{array}{l}\text { Ripening } \\
\text { condition }\end{array}$} & Growth phase & \multicolumn{2}{|c|}{ Death phase } & & & & & & \\
\hline & $\theta$ & $\mathrm{RH}$ & $\mu_{\mathrm{KM}} \pm \mathrm{SD}$ & $\mathrm{D}_{\mathrm{KM}} \pm \mathrm{SD}$ & $t_{\text {DKM }}$ & $\mu_{\mathrm{GC}} \pm \mathrm{SD}$ & $\mathrm{t}_{\mu \mathrm{GC}}$ & $\mu_{\mathrm{BA}} \pm \mathrm{SD}$ & $\mathrm{t}_{\mu \mathrm{BA}}$ & $\mu_{\mathrm{PC}} \pm \mathrm{SD}(/ \mathrm{d})$ & $\mathrm{t}_{\mu \mathrm{PC}}$ \\
\hline 1 & 8 & 88 & $0.24 \pm 0.07$ & $0.044 \pm 0.006$ & 33.3 & $0.72 \pm 0.02$ & 4.5 & $0.26 \pm 0.06$ & 34.5 & $0.04 \pm 0.05$ & 33.7 \\
\hline 2 & 8 & 92 & $0.22 \pm 0.05$ & $0.043 \pm 0.009$ & 30.6 & $0.62 \pm 0.05$ & 4.4 & $0.24 \pm 0.05$ & 35.6 & $0.14 \pm 0.03$ & 19.3 \\
\hline 3 & 8 & 98 & $0.22 \pm 0.05$ & $0.044 \pm 0.006$ & 30.3 & $0.72 \pm 0.03$ & 4.5 & $0.27 \pm 0.03$ & 34.1 & $0.13 \pm 0.03$ & 19.8 \\
\hline 4 & 8 & 98 & $0.21 \pm 0.07$ & $0.038 \pm 0.008$ & 29.9 & $0.68 \pm 0.07$ & 4.5 & $0.23 \pm 0.04$ & 34.5 & $0.12 \pm 0.05$ & 19.6 \\
\hline 3 and 4 & 8 & 98 & $0.21 \pm 0.06$ & $0.041 \pm 0.008$ & 30.1 & $0.70 \pm 0.05$ & 4.5 & $0.25 \pm 0.05$ & 34.3 & $0.12 \pm 0.5$ & 19.7 \\
\hline 5 & 12 & 88 & $0.32 \pm 0.04$ & $0.049 \pm 0.008$ & 29.8 & $0.96 \pm 0.03$ & 3.8 & $0.5 \pm 0.2$ & 16.2 & $0.07 \pm 0.02$ & 20.5 \\
\hline 6 & 12 & 92 & $0.50 \pm 0.08$ & $0.050 \pm 0.009$ & 30.3 & $1.04 \pm 0.05$ & 3.7 & $0.57 \pm 0.02$ & 15.0 & $0.60 \pm 0.2$ & 9.2 \\
\hline 7 & 12 & 92 & $0.48 \pm 0.07$ & $0.049 \pm 0.009$ & 30.2 & $1.04 \pm 0.03$ & 3.9 & $0.57 \pm 0.04$ & 15.1 & $0.5 \pm 0.1$ & 9.5 \\
\hline 8 & 12 & 92 & $0.50 \pm 0.07$ & $0.049 \pm 0.008$ & 29.5 & $0.91 \pm 0.06$ & 3.7 & $0.58 \pm 0.09$ & 15.0 & $0.5 \pm 0.1$ & 10.0 \\
\hline 9 & 12 & 92 & $0.46 \pm 0.07$ & $0.052 \pm 0.008$ & 29.6 & $0.9 \pm 0.1$ & 3.8 & $0.60 \pm 0.09$ & 14.9 & $0.55 \pm 0.07$ & 9.9 \\
\hline 10 & 12 & 92 & $0.56 \pm 0.09$ & $0.049 \pm 0.008$ & 29.4 & $1.0 \pm 0.1$ & 3.6 & $0.59 \pm 0.09$ & 14.9 & $0.5 \pm 0.1$ & 9.8 \\
\hline 6 to 10 & 12 & 92 & $0.50 \pm 0.07$ & $0.050 \pm 0.007$ & 29.8 & $1.0 \pm 0.1$ & 3.7 & $0.58 \pm 0.09$ & 15.0 & $0.53 \pm 0.1$ & 9.7 \\
\hline 11 & 12 & 98 & $0.58 \pm 0.07$ & $0.053 \pm 0.008$ & 30.7 & $0.96 \pm 0.03$ & 3.8 & $0.69 \pm 0.09$ & 13.0 & $0.7 \pm 0.1$ & 12.8 \\
\hline 12 & 16 & 88 & $0.9 \pm 0.1$ & $0.070 \pm 0.006$ & 27.9 & $1.57 \pm 0.07$ & 4.2 & $0.69 \pm 0.09$ & 12.5 & $0.03 \pm 0.04$ & 10.7 \\
\hline 13 & 16 & 88 & $0.94 \pm 0.07$ & $0.072 \pm 0.006$ & 27.8 & $1.6 \pm 0.1$ & 4.1 & $0.65 \pm 0.08$ & 12.7 & $0.03 \pm 0.03$ & 10.7 \\
\hline 12 and 13 & 16 & 88 & $0.92 \pm 0.08$ & $0.071 \pm 0.006$ & 27.9 & $1.59 \pm 0.08$ & 4.1 & $0.67 \pm 0.09$ & 12.6 & $0.03 \pm 0.04$ & 10.7 \\
\hline 14 & 16 & 92 & $0.98 \pm 0.06$ & $0.066 \pm 0.009$ & 27.9 & $1.8 \pm 0.1$ & 3.8 & $0.9 \pm 0.1$ & 11.8 & $0.32 \pm 0.06$ & 10.8 \\
\hline 15 & 16 & 98 & $0.9 \pm 0.1$ & $0.069 \pm 0.005$ & 25.1 & $1.7 \pm 0.1$ & 4.2 & $1.4 \pm 0.2$ & 12.4 & $3.2 \pm 0.6$ & 8.7 \\
\hline
\end{tabular}

Variables: $\mu_{\mathrm{KM}}, \mathrm{D}_{\mathrm{KM}}, \mu_{\mathrm{GC}}, \mu_{\mathrm{BA}}$, and $\mu_{\mathrm{PC}}=$ maximal growth and death rates of K. marxianus, maximal growth rates of $G$. candidum and B. aurantiacum, and maximal sporulation O rate of $P$. camemberti (per day), respectively (rates were determined from Weibull models); $\mathrm{t}_{\mathrm{DKM}}, \mathrm{t}_{\mu \mathrm{GC}}, \mathrm{t}_{\mu \mathrm{BA}}$, and $\mathrm{t}_{\mu \mathrm{PC}}=\mathrm{times}$ associated with $\mathrm{D}_{\mathrm{KM}}, \mu_{\mathrm{GC}}$, $\mu_{\mathrm{BA}}$, and $\mu_{\mathrm{PC}}$, given with an SD of $0.1 \mathrm{~d}$. Each Weibull model had a coefficient of determination of $>0.98$ and is given with $P>0.01$. The df of $\mu_{\mathrm{KM}}$, $\mathrm{D}_{\mathrm{KM}}, \mu_{\mathrm{GC}}, \mu_{\mathrm{BA}}$, and $\mu_{\mathrm{PC}}$ determinations were equal to $45,17,51,36$, and 51 , respectively. Rows in bold represent the means of the lines above. 
Table 2. Values of kinetic descriptors of $\mathrm{pH}$ in the rind, and lactose and lactate concentrations in the rind and in the core of Camembert-type cheeses throughout ripening for each temperature $\left(\theta,{ }^{\circ} \mathrm{C}\right)$ and relative humidity $(\mathrm{RH}, \%)$ during Camembert-type cheese ripening in the chamber ${ }^{1}$

\begin{tabular}{|c|c|c|c|c|c|c|c|c|c|c|c|c|}
\hline \multirow[b]{3}{*}{ Run no. } & & & & & \multicolumn{4}{|c|}{ Lactose } & \multicolumn{4}{|c|}{ Lactate } \\
\hline & \multicolumn{2}{|c|}{$\begin{array}{l}\text { Ripening } \\
\text { condition }\end{array}$} & \multicolumn{2}{|c|}{$\begin{array}{l}\mathrm{pH} \text { of } \\
\text { the rind }\end{array}$} & \multicolumn{2}{|c|}{$\begin{array}{l}\text { Consumption } \\
\text { in the rind }\end{array}$} & \multicolumn{2}{|c|}{$\begin{array}{l}\text { Decrease } \\
\text { in the core }\end{array}$} & \multicolumn{2}{|c|}{$\begin{array}{l}\text { Consumption } \\
\text { in the rind }\end{array}$} & \multicolumn{2}{|c|}{$\begin{array}{l}\text { Decrease } \\
\text { in the core }\end{array}$} \\
\hline & $\theta$ & $\mathrm{RH}$ & $\mathrm{V}_{\mathrm{pH}}$ & $t_{\mathrm{V}_{\mathrm{pH}}}$ & $\mathrm{C}_{\mathrm{LO}}$ & $\mathrm{t}_{\mathrm{CLO}}$ & $\mathrm{D}_{\mathrm{LO}}$ & $\mathrm{t}_{\mathrm{DLO}}$ & $\mathrm{C}_{\mathrm{LA}}$ & $\mathrm{t}_{\mathrm{CLA}}$ & $\mathrm{D}_{\mathrm{LA}}$ & $t_{\text {DLA }}$ \\
\hline 1 & 8 & 88 & 1.2 & 9.5 & 1.59 & 5.5 & 0.83 & 5.6 & 1.97 & 7.5 & 1.01 & 10.9 \\
\hline 2 & 8 & 92 & 0.9 & 9.4 & 2.00 & 5.0 & 1.07 & 5.5 & 2.70 & 7.5 & 1.12 & 10.9 \\
\hline 3 and 4 & 8 & 98 & 1.1 & 9.4 & 1.80 & 4.9 & 0.77 & 5.5 & 3.44 & 7.5 & 0.86 & 10.8 \\
\hline 5 & 12 & 88 & 1.4 & 6.6 & 2.09 & 2.6 & 1.71 & 3.9 & 3.24 & 6.9 & 2.73 & 7.4 \\
\hline 6 & 12 & 92 & 1.3 & 6.6 & 3.00 & 2.6 & 1.53 & 3.9 & 3.11 & 6.8 & 1.88 & 7.6 \\
\hline 7 & 12 & 92 & 1.3 & 6.6 & 3.01 & 2.6 & 1.58 & 3.9 & 3.11 & 6.8 & 1.79 & 7.6 \\
\hline 8 & 12 & 92 & 1.3 & 6.7 & 3.09 & 2.6 & 1.57 & 3.9 & 3.08 & 6.8 & 1.83 & 7.7 \\
\hline 9 & 12 & 92 & 1.3 & 6.6 & 3.10 & 2.7 & 1.54 & 3.9 & 3.12 & 6.8 & 1.78 & 7.7 \\
\hline 13 & 16 & 88 & 4.9 & 5.1 & 5.50 & 1.1 & 1.71 & 3.3 & 5.80 & 5.0 & 2.04 & 5.4 \\
\hline 12 and 13 & 16 & 88 & 4.8 & 5.1 & 5.45 & 1.1 & 1.77 & 3.3 & 5.83 & 5.0 & 2.02 & 5.4 \\
\hline 14 & 16 & 92 & 2.0 & 5.2 & 8.10 & 1.2 & 1.82 & 3.3 & 3.97 & 5.0 & 1.84 & 5.5 \\
\hline 15 & 16 & 98 & 2.1 & 5.1 & 7.12 & 1.3 & 1.93 & 3.4 & 2.24 & 5.00 & 1.65 & 5.5 \\
\hline
\end{tabular}

${ }^{1}$ Variables: $\mathrm{V}_{\mathrm{pH}}=$ maximal rate of $\mathrm{pH}$ increase in the rind ( $\mathrm{pH}$ units/d), determined from the slope of Weibull modeling and given with an $\mathrm{SD}$ of 0.1 unit; $\mathrm{t}_{\mathrm{VpH}}=$ time associated with $\mathrm{V}_{\mathrm{pH}}(\mathrm{d})$, given with an $\mathrm{SD}$ of $0.1 \mathrm{~d} ; \mathrm{C}_{\mathrm{LO}}$ and $\mathrm{D}_{\mathrm{LO}}=$ maximal consumption or decreasing rates of lactose $(\mathrm{LO})$ in the rind and in the core, respectively ( $\mathrm{g}$ of lactose $/ \mathrm{kg}$ per day); $\mathrm{C}_{\mathrm{LA}}$ and $\mathrm{D}_{\mathrm{LA}}=$ maximal consumption or decreasing rates of lactate (LA) in the rind and in the core ( $\mathrm{g}$ of lactate $/ \mathrm{kg}$ per day). These rates are determined from the slope of Weibull modeling and given with an SD of $0.05 ; \mathrm{t}_{\mathrm{CLO}}, \mathrm{t}_{\mathrm{DLO}}, \mathrm{t}_{\mathrm{CLA}}$, and $\mathrm{t}_{\mathrm{DLA}}=$ times (in d) for which $\mathrm{C}_{\mathrm{LO}}, \mathrm{D}_{\mathrm{LO}}, \mathrm{C}_{\mathrm{LA}}$, and $\mathrm{D}_{\mathrm{LA}}$ were obtained, respectively, given with an $\mathrm{SD}$ of $0.1 \mathrm{~d}$. Whatever the Weibull model, the coefficient of determination was $>0.99$, and $P>0.01$. The $\mathrm{df}$ for the Weibull models was equal to 203 for the pH in the rind, 34 for lactose, and 26 for lactate. Rows in bold represent the means of the lines above.

ing to the Mann-Whitney method (Cohen, 1992). For each run, the changes in each ripening parameter, in relation to time, were described by 2 descriptors calculated using the Weibull model (Schepers et al., 2000) with Statistica and are defined in the first part of the Results and Discussion section.

The general linear model (Statistica software) was used to calculate quadratic models, making it possible to determine the influence of the 2 factors (temperature, $\theta$; relative humidity, $\mathbf{R H}$ ) on the kinetic descriptors. By using the Stepwise Backward (Statistica) procedure, the nonsignificant terms were omitted one by one. Consequently, only the terms significant at a $99 \%$ confidence level $(P<0.01)$ were taken into count. The 3-dimensional response surfaces of some descriptors versus temperature and $\mathrm{RH}$ factors were plotted to illustrate the main effects (linear or quadratic), interactive effects, or both.

\section{RESULTS AND DISCUSSION}

Whatever the run, on d 0 , the average decimal logarithms of viable cell concentrations, calculated from all the runs, were $5.2 \pm 0.2,2.1 \pm 0.1$, and $4.9 \pm 0.3 \mathrm{cfu} / \mathrm{g}$ for K. marxianus, G. candidum, and B. aurantiacum, respectively, and $3.8 \pm 0.1$ spores/g for $P$. camemberti. The chemical composition of the rind was as follows: $\mathrm{DM}$ content $=41.3 \pm 0.6 \%, \mathrm{pH}=4.80 \pm 0.05$, lactose concentration $=13.7 \pm 0.4 \mathrm{~g} / \mathrm{kg}$, lactate concentration $=14.0 \pm 0.6 \mathrm{~g} / \mathrm{kg}$. The chemical composition of the core was as follows: DM content $=39.0 \pm 0.8 \%$, lactose concentration $=14.3 \pm 0.5 \mathrm{~g} / \mathrm{kg}$, and lactate concentration $=15 \pm 1 \mathrm{~g} / \mathrm{kg}$.

\section{Description of Phenomena Observed at $12^{\circ} \mathrm{C}$ and $92 \%$ RH (for the 5 Central Point Runs): Statistical Run Reproducibility}

For the central point runs (runs 6 to 10), the reproducibility of the microbiological (viable cell counts) and physicochemical measurements (carbon substrate concentrations, $\mathrm{pH}$, and cheese underrind thickness) were studied in relation to ripening time. From the 2-factor (run, time) ANOVA results, it was apparent that 1) the hypotheses of equality of the evolutions were satisfactory with a risk $\alpha=0.01$, and 2) the risks of a false 
Table 3. Values of descriptors of cheese water mass loss $\left(\mathrm{L}_{\mathrm{H} 2 \mathrm{O}}\right)$ between $\mathrm{d} 14$ and 0 , and underrind thickness for each temperature $\left(\theta,{ }^{\circ} \mathrm{C}\right)$ and relative humidity $(\mathrm{RH}, \%)$ in the Camembert-type cheese ripening chamber ${ }^{1}$

\begin{tabular}{|c|c|c|c|c|c|c|}
\hline \multirow[b]{2}{*}{ Run number } & \multicolumn{2}{|c|}{ Ripening condition } & \multirow{2}{*}{$\begin{array}{c}\mathrm{L}_{\mathrm{H} 2 \mathrm{O}} \pm \mathrm{SD} \\
(\mathrm{g} / \mathrm{d})\end{array}$} & \multicolumn{3}{|c|}{ Underrind thickness } \\
\hline & $\theta\left({ }^{\circ} \mathrm{C}\right)$ & $\mathrm{RH}(\%)$ & & $\mathrm{t}_{\mathrm{UR}, \mathrm{i}}(\mathrm{d})$ & $\mathrm{V}_{\mathrm{TUR}} \pm \mathrm{SD}(\mathrm{mm} / \mathrm{d})$ & $t_{\text {VTUR }}$ \\
\hline \multicolumn{7}{|l|}{ Run } \\
\hline 1 & 8 & 88 & $1.2 \pm 0.3$ & 9.0 & $0.50 \pm 0.05$ & 30.4 \\
\hline 2 & 8 & 92 & $1.0 \pm 0.1$ & 9.0 & $0.46 \pm 0.07$ & 29.8 \\
\hline 3 & 8 & 98 & $0.7 \pm 0.1$ & 9.0 & $0.59 \pm 0.06$ & 29.4 \\
\hline 4 & 8 & 98 & $0.6 \pm 0.1$ & 9.0 & $0.57 \pm 0.06$ & 29.4 \\
\hline 3 and 4 & 8 & 98 & $0.6 \pm 0.1$ & 9.0 & $0.58 \pm 0.06$ & 29.4 \\
\hline 5 & 12 & 88 & $2.1 \pm 0.2$ & 7.0 & $0.62 \pm 0.04$ & 29.3 \\
\hline 6 & 12 & 92 & $1.7 \pm 0.3$ & 7.0 & $0.63 \pm 0.05$ & 29.5 \\
\hline 7 & 12 & 92 & $1.5 \pm 0.3$ & 7.0 & $0.59 \pm 0.04$ & 29.6 \\
\hline 8 & 12 & 92 & $1.7 \pm 0.3$ & 7.0 & $0.58 \pm 0.07$ & 29.5 \\
\hline 9 & 12 & 92 & $1.6 \pm 0.3$ & 7.0 & $0.59 \pm 0.05$ & 29.5 \\
\hline 10 & 12 & 92 & $1.6 \pm 0.3$ & 7.0 & $0.62 \pm 0.05$ & 29.5 \\
\hline 6 to 10 & 12 & 92 & $1.6 \pm 0.3$ & 7.0 & $0.60 \pm 0.06$ & 29.5 \\
\hline 11 & 12 & 98 & $1.2 \pm 0.2$ & 7.0 & $0.85 \pm 0.04$ & 29.2 \\
\hline 12 & 16 & 88 & $2.5 \pm 0.3$ & 5.0 & $0.80 \pm 0.07$ & 20.8 \\
\hline 13 & 16 & 88 & $2.6 \pm 0.3$ & 5.0 & $0.86 \pm 0.06$ & 20.7 \\
\hline 12 and 13 & 16 & 88 & $2.6 \pm 0.3$ & 5.0 & $0.83 \pm 0.07$ & 20.8 \\
\hline 14 & 16 & 92 & $2.2 \pm 0.1$ & 5.0 & $1.14 \pm 0.07$ & 20.5 \\
\hline 15 & 16 & 98 & $1.8 \pm 0.2$ & 5.0 & $1.18 \pm 0.06$ & 20.5 \\
\hline
\end{tabular}

${ }^{1} \mathrm{~L}_{\mathrm{H} 2 \mathrm{O}}=$ water loss rate $(\mathrm{g} / \mathrm{d})$, calculated from 20 cheeses/run and between $\mathrm{d} 0$ and $14 ; \mathrm{t}_{\mathrm{UR}, \mathrm{i}}=$ time during which the underrind became observable (in d): $V_{\text {TUR }}=$ maximal increasing rate of underrind thickness (in $\mathrm{mm} / \mathrm{d}$ ) determined from the slope of Weibull modeling; $t_{\mathrm{VTUR}}=$ time during which $\mathrm{V}_{\mathrm{TUR}}$ was obtained, given with an SD of $0.1 \mathrm{~d}$. The Weibull models are given with $P<0.01$ and with a coefficient of determination of $>0.98$. The df of these Weibull models was 203. Rows in bold represent the means of the lines above.

interpretation estimated by the test power $(1-\beta)$ were less than 0.94. Throughout the experimental period, the runs carried out under the same conditions were statistically identical. This is shown in Figure 1, which gives the 4 microbial evolutions in relation to ripening time.

\section{Microbial Evolutions}

Figure 1 provides the decimal logarithm evolutions in K. marxianus, G. candidum, and B. aurantiacum viable cell concentrations and spore concentration of $P$. camemberti in relation to time for the central point runs, as well as their Weibull modeling. Whatever the microorganism, the evolution in their concentrations showed the same patterns as those described previously by Leclercq-Perlat et al. (2004, 2006) under similar ripening conditions.

For $K$. marxianus, the maximum growth rate $\left(\mu_{\mathrm{KM}}\right.$, where KM is $K$. marxianus) was $0.50 \pm 0.07 / \mathrm{d}$ (Table 1) and occurred at $1.50 \pm 0.05 \mathrm{~d}\left(\mathrm{t}_{\mu \mathrm{KM}}\right.$; results not shown). The maximal cell concentration of $K$. marxianus was approximately $3.2 \times 10^{7} \mathrm{cfu} / \mathrm{g}$. From d 14 to 40 , the $K$. marxianus cell concentration displayed a death phase, with a maximal death rate $\left(\mathrm{D}_{\mathrm{KM}}\right)$ of 0.050 $\pm 0.007 / \mathrm{d}$ occurring at $29.8 \pm 0.2 \mathrm{~d}$ (Table 1 ). For $G$. candidum, the maximal growth rate $\left(\mu_{\mathrm{GC}}\right.$, where $\mathrm{GC}$ is
G. candidum) was $1.0 \pm 0.1 / \mathrm{d}$ and occurred at $3.7 \pm$ $0.1 \mathrm{~d}\left(\mathrm{t}_{\mu \mathrm{GC}} ;\right.$ Table 1$)$. After d 8, the G. candidum viable cell concentration remained constant, at approximately $2.6 \times 10^{7} \mathrm{cfu} / \mathrm{g}$. For B. aurantiacum, from d 9 to 25 , the maximal growth rate $\left(\mu_{\mathrm{BA}}\right.$, where $\mathrm{BA}$ is $B$. aurantiacum) was $0.58 \pm 0.09 / \mathrm{d}$ and occurred at $15.0 \pm 0.2 \mathrm{~d}$ $\left(\mathrm{t}_{\mu \mathrm{BA}}\right.$; Table 1$)$. From d 26 to 40, a second growth phase took place and reached a value close to $7.9 \times 10^{8} \mathrm{cfu} / \mathrm{g}$ on $\mathrm{d} 40$. For P. camemberti, the maximal sporulation rate $\left(\mu_{\mathrm{PC}}\right.$, where $\mathrm{PC}$ is $P$. camemberti) was $0.5 \pm 0.1 / \mathrm{d}$ and occurred at $9.7 \pm 0.6 \mathrm{~d}\left(\mathrm{t}_{\mu \mathrm{PC}}\right.$; Table 1$)$.

Except for $K$. marxianus, the values of the kinetic descriptors (Table 1) were in accordance with the ones obtained previously (Leclercq-Perlat et al., 2006). For $K$. marxianus, the growth and death rates were higher than those found by Leclercq-Perlat et al. (2006), which can be explained by differences in the modeling methods: in the 2006 study, these authors calculated mean rates.

\section{Biochemical Changes}

For the central point runs, the evolution in $\mathrm{pH}$, carbon substrate concentrations, and cheese underrind thicknesses showed the same phases of ripening as those described previously (Leclercq-Perlat et al., 2004, 2006) under similar ripening conditions. Their kinetic 


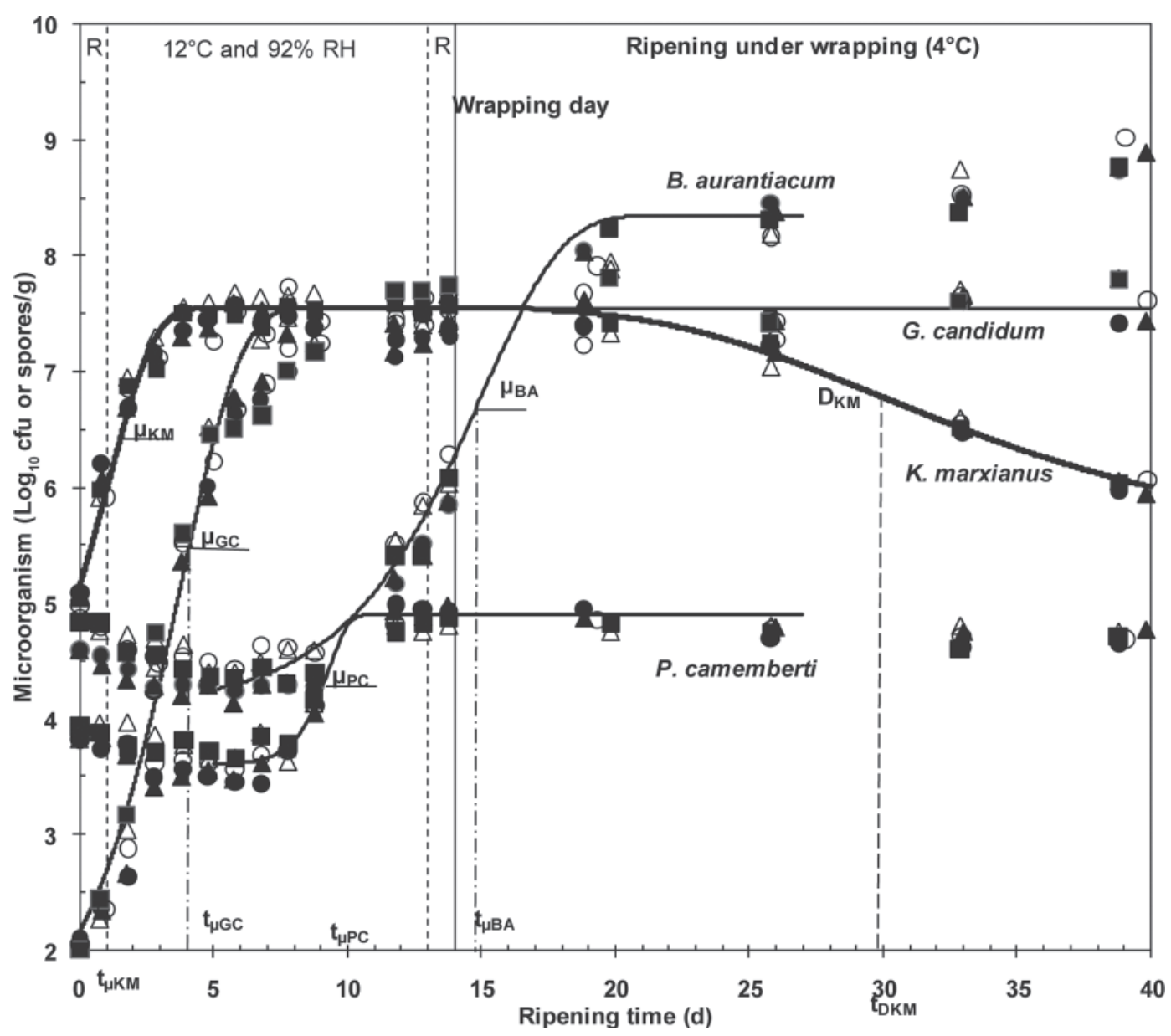

Figure 1. Evolution of the decimal logarithm of Kluyveromyces marxianus (KM), Geotrichum candidum (GC), and Brevibacterium aurantiacum (BA) viable cell concentrations as well as that of Penicillium camemberti (PC) spore concentrations in relation to ripening time for runs 6 $(\bullet), 7(\boldsymbol{\Delta}), 8(\Delta), 9(\boldsymbol{\square})$, and $10(\bigcirc)$ carried out under central point ripening conditions $\left(12^{\circ} \mathrm{C}, 92 \% \mathrm{RH}\right)$. $\mathrm{R}=$ surface drying phases carried out under $12^{\circ} \mathrm{C}$ and $85 \%$ of $\mathrm{RH} ; \mu_{\mathrm{KM}}, \mu_{\mathrm{GC}}, \mu_{\mathrm{BA}}$, and $\mu_{\mathrm{PC}}=$ maximal growth rates (per day) of $\mathrm{KM}, \mathrm{GC}$, BA, and PC, respectively, were obtained by calculating the slope of the first Weibull model (solid lines); $\mathrm{t}_{\mu \mathrm{KM}}, \mathrm{t}_{\mu \mathrm{GC}}, \mathrm{t}_{\mu \mathrm{BA}}$, and $\mathrm{t}_{\mu \mathrm{PC}}=$ days for which $\mu_{\mathrm{KM}}, \mu_{\mathrm{GC}}, \mu_{\mathrm{BA}}$, and $\mu_{\mathrm{PC}}$ were obtained; $\mathrm{D}_{\mathrm{KM}}=$ maximal death rate (per day) of KM, obtained by calculating the slope of the death phase from the Weibull model $\left(\right.$ solid lines); $t_{\mathrm{DKM}}=$ day for which $\mathrm{D}_{\mathrm{KM}}$ was obtained.

descriptors were determined using Weibull modeling (Bonaïti et al., 2004).

pH of Surface. Figure 2 shows the evolutions in $\mathrm{pH}$ and their Weibull curves in relation to ripening time for the 9 conditions of temperature and RH. For the central point runs, the maximal rate of $\mathrm{pH}$ increase $\left(\mathrm{V}_{\mathrm{pH}}\right)$ was $1.3 \pm 0.1 \mathrm{pH}$ units/d and occurred at 6.60 $\pm 0.1 \mathrm{~d}$ (Table 2). After wrapping, rind $\mathrm{pH}$ remained constant at $7.7 \pm 0.2$.

Carbon Substrates. Figure 3 shows the evolutions in lactose (panel A) and lactate (panel B) concentrations $(\mathrm{g} / \mathrm{kg})$ in the rind throughout ripening, whatever the temperature and $\mathrm{RH}$ among the 9 conditions. For the central point runs $\left(12^{\circ} \mathrm{C}, 92 \% \mathrm{RH}\right)$, lactose concentrations in the rind and in the core decreased and became negligible on d 8 to 9 and on d 19, respectively.
The kinetic descriptors were as follows. The maximal consumption rate in the rind $\left(\mathrm{C}_{\mathrm{LO}}\right.$, where $\mathrm{LO}$ is lactose $)$ was equal to $3.05 \pm 0.07 \mathrm{~g} / \mathrm{kg}$ per day and occurred at $2.6 \pm 0.1 \mathrm{~d}\left(\mathrm{t}_{\mathrm{CLO}}\right)$, whereas the maximal rate of decrease in the core $\left(\mathrm{D}_{\mathrm{LO}}\right)$ was equal to $1.55 \pm 0.06 \mathrm{~g} /$ $\mathrm{kg}$ per day and occurred at $3.9 \pm 0.1 \mathrm{~d}\left(\mathrm{t}_{\mathrm{DLO}}\right.$; Table 2$)$.

Whatever the cheese part, from $\mathrm{d} 0$ to $\mathrm{d} 4-6$ the mean evolution of lactate concentration presented from the beginning phase, during which it increased, corresponding to a postacidification phenomenon (Lenoir et al., 1985; Leclercq-Perlat et al., 2004, 2006). Then, until d 14 in the rind and d 20 in the core, corresponding to a phase during which lactate concentration decreased faster, the mean lactate concentration kinetic descriptors were as follows: the maximal consumption rate in the rind $\left(\mathrm{C}_{\mathrm{LA}}\right.$, where $\mathrm{LA}$ is lactate) was equal 


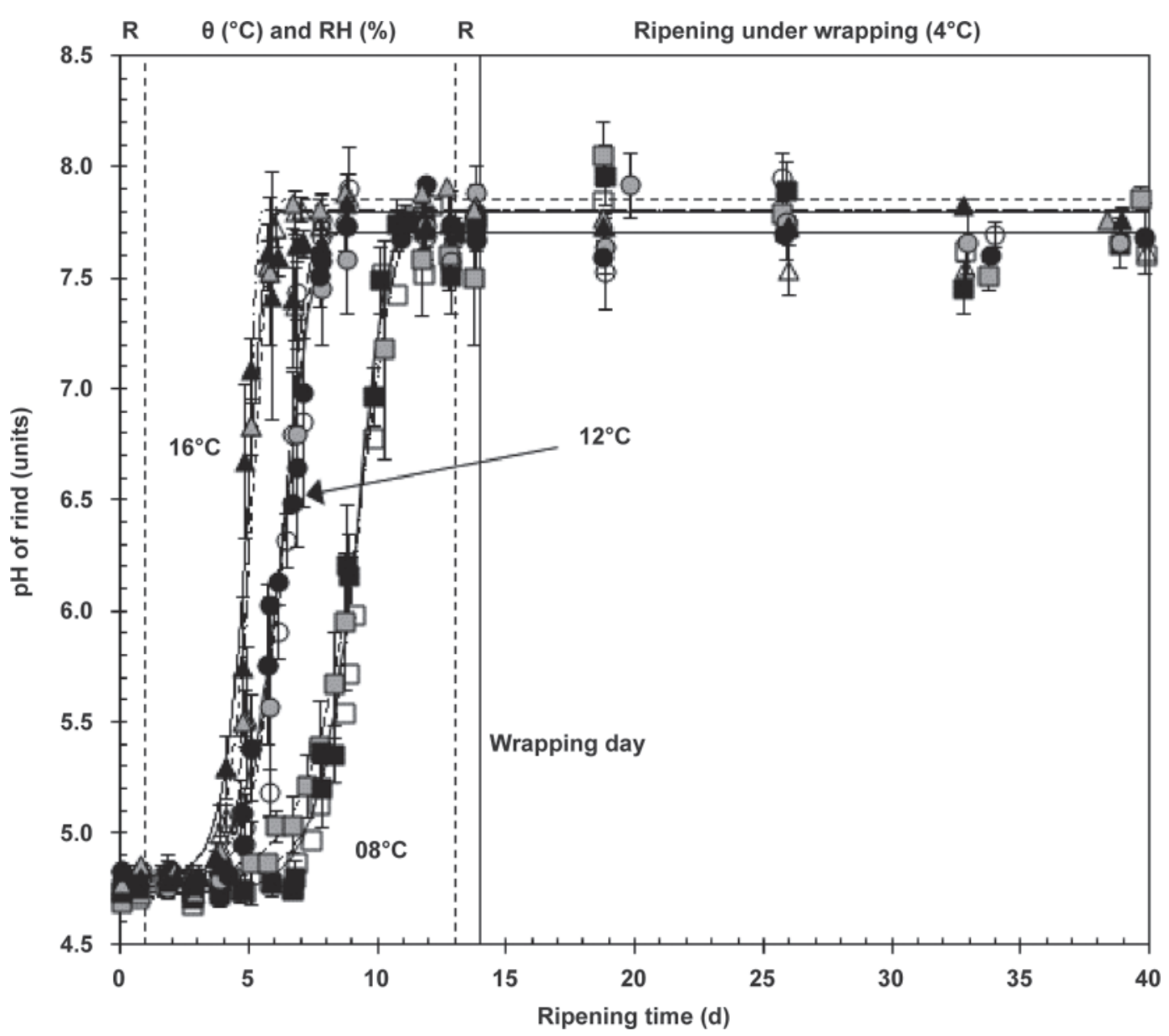

Figure 2. Increase in $\mathrm{pH}$ in the rind of a Camembert-type cheese in relation to ripening time for the 9 ripening conditions of temperature and $\mathrm{RH}$, and determination of their kinetic descriptors from the Weibull model. The symbols give the experimental points and the line associated with the Weibull model. Each run of the experimental design is represented as follows: (open triangles and dashed-dotted line) $16^{\circ} \mathrm{C}$ and $88 \% \mathrm{RH}$; (gray triangles and dashed line) $16^{\circ} \mathrm{C}$ and $92 \% \mathrm{RH}$; (solid triangles and solid line) $16^{\circ} \mathrm{C}$ and $98 \% \mathrm{RH}$; (open circles and dotted-dashed line) $12^{\circ} \mathrm{C}$ and $92 \% \mathrm{RH}$; (gray circles and dashed line) $12^{\circ} \mathrm{C}$ and $92 \% \mathrm{RH}$; (solid circles and solid line) $12^{\circ} \mathrm{C}$ and $98 \% \mathrm{RH}$ : (open squares and dashed-dotted line) $8^{\circ} \mathrm{C}$ and $98 \% \mathrm{RH}$; (gray squares and dashed line) $8^{\circ} \mathrm{C}$ and $92 \% \mathrm{RH}$; and (solid squares and solid line) $8^{\circ} \mathrm{C}$ and $98 \% \mathrm{RH}$. R $=$ surface drying phases carried out under $12^{\circ} \mathrm{C}$ and $85 \% \mathrm{RH}$. The central point conditions are given as the average of the 5 runs carried out under $12^{\circ} \mathrm{C}$ and $92 \% \mathrm{RH}$. For each experimental point, the error bars represent SD.

to $3.11 \pm 0.05 \mathrm{~g} / \mathrm{kg}$ per day and occurred at $6.8 \pm 0.1$ $\mathrm{d}\left(\mathrm{t}_{\mathrm{CLA}}\right)$, whereas the maximal consumption rate in the core $\left(\mathrm{D}_{\mathrm{LA}}\right)$ was equal to $1.82 \pm 0.07 \mathrm{~g} / \mathrm{kg}$ per day and occurred at $7.6 \pm 0.1 \mathrm{~d}\left(\mathrm{t}_{\mathrm{DLA}}\right.$; Table 2$)$. From $\mathrm{d} 20$ to 40 , lactate concentrations in the 2 parts continued to decrease, reaching 0.5 and $0.9 \mathrm{~g}$ of lactate $/ \mathrm{kg}$ in the rind and in the core, respectively, on d 40 (Figure 3). Leclercq-Perlat et al. (2006) found the same range of kinetic descriptor values for the $\mathrm{pH}$ of the rind as well as for lactose and lactate concentrations under similar ripening conditions.

Cheese Water Mass Loss and Underrind Thickness. From d 0 to 14, the mean water weight loss decreased linearly as shown previously (Bonaiti et al., 2004), and the mean water mass loss rate $\left(\mathrm{L}_{\mathrm{H} 2 \mathrm{O}}\right)$ was $1.6 \pm 0.3 \mathrm{~g} / \mathrm{d}$ for the central point runs (Table 3 ).
The development of the cheese underrind, in relation to ripening time, provides information on how ripe the cheese is. Figure 4 presents the evolution in underrind thickness $(\mathrm{mm})$ throughout ripening under the 9 ripening conditions. Under central point conditions, from d 0 to 7 , the underrind was not observable, making it possible to define the day on which the underrind became merely observable $\left(t_{U R, i}=7 \mathrm{~d}\right)$. The mean underrind thickness was measurable $1 \mathrm{~d}$ later. Then, and until the end of ripening, the mean cheese underrind thickness increased at the maximal rate of increase $\left(\mathrm{V}_{\mathrm{TUR}}\right)$, equal to $0.60 \pm 0.05 \mathrm{~mm} / \mathrm{d}$, which occurred on d 29.5 ( $\mathrm{t}_{\mathrm{VTUR}}$; Table 3).

In conclusion, the central point runs were both reproducible and repeatable. Indeed, regardless of the microbial or biochemical parameters, the standard 

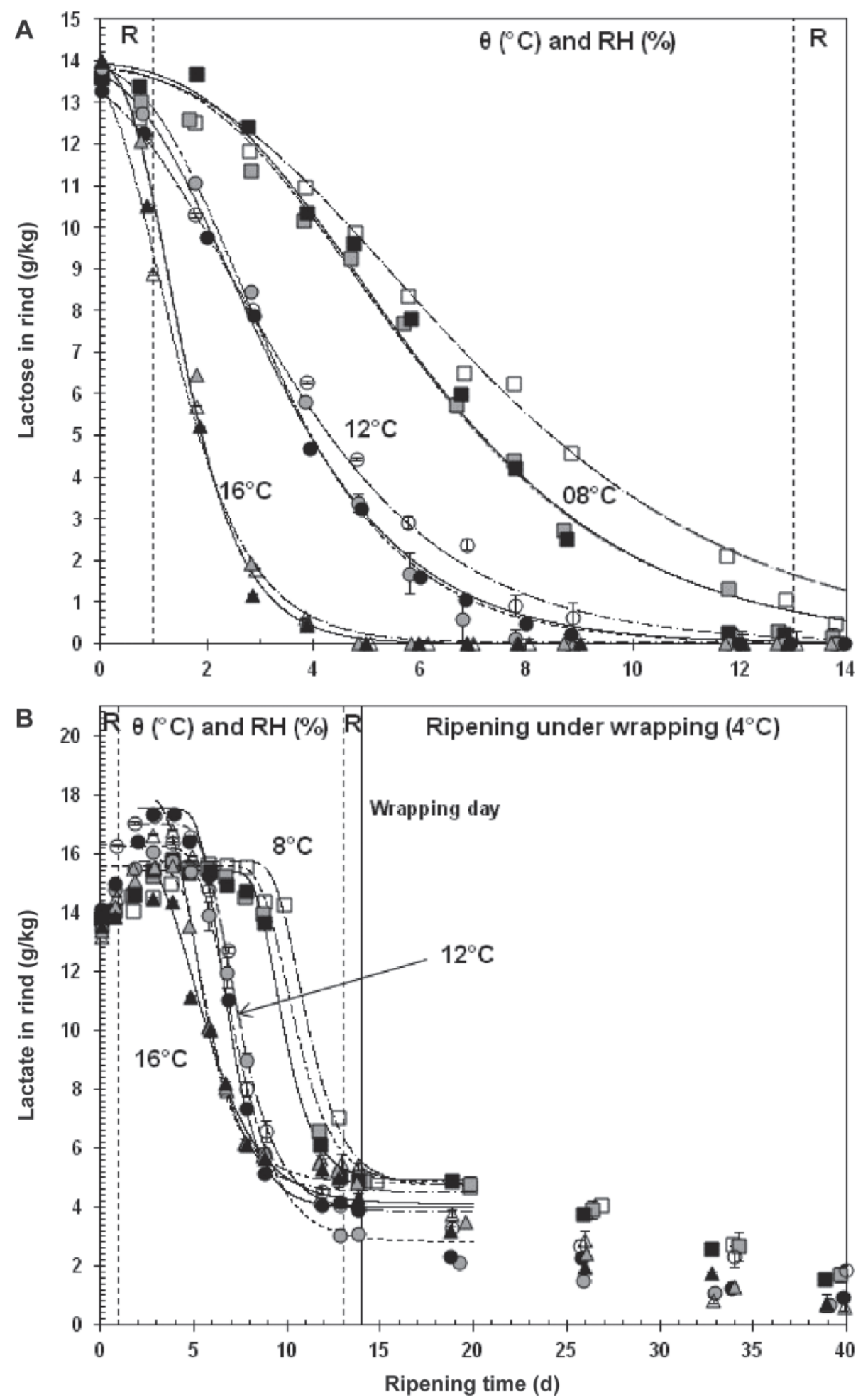

Figure 3. Evolution of lactose (A) and lactate (B) concentrations of the rind in relation to ripening time for the 9 ripening conditions of temperature and $\mathrm{RH}$, and determination of their kinetic descriptors from the Weibull model. The symbols give the experimental points and the line associated with the Weibull model. Each run of the experimental design is represented as follows: (open triangles and dashed-dotted line) $16^{\circ} \mathrm{C}$ and $88 \% \mathrm{RH}$; (gray triangles and dashed line) $16^{\circ} \mathrm{C}$ and $92 \% \mathrm{RH}$; (solid triangles and solid line) $16^{\circ} \mathrm{C}$ and $98 \% \mathrm{RH}$; (open circles and dotted-dashed line) $12^{\circ} \mathrm{C}$ and $92 \% \mathrm{RH}$; (gray circles and dashed line) $12^{\circ} \mathrm{C}$ and $92 \% \mathrm{RH}$; (solid circles and solid line) $12^{\circ} \mathrm{C}$ and $98 \% \mathrm{RH}$; (open squares and dashed-dotted line) $8^{\circ} \mathrm{C}$ and $98 \% \mathrm{RH}$; (gray squares and dashed line) $8^{\circ} \mathrm{C}$ and $92 \% \mathrm{RH}$; and (solid squares and solid line) $8^{\circ} \mathrm{C}$ and $98 \%$ RH. R = surface drying phases carried out under $12^{\circ} \mathrm{C}$ and $85 \% \mathrm{RH}$. The central point conditions are given as the average of the 5 runs carried out under $12^{\circ} \mathrm{C}$ and $92 \% \mathrm{RH}$ and the error bars represent the standard deviation. 

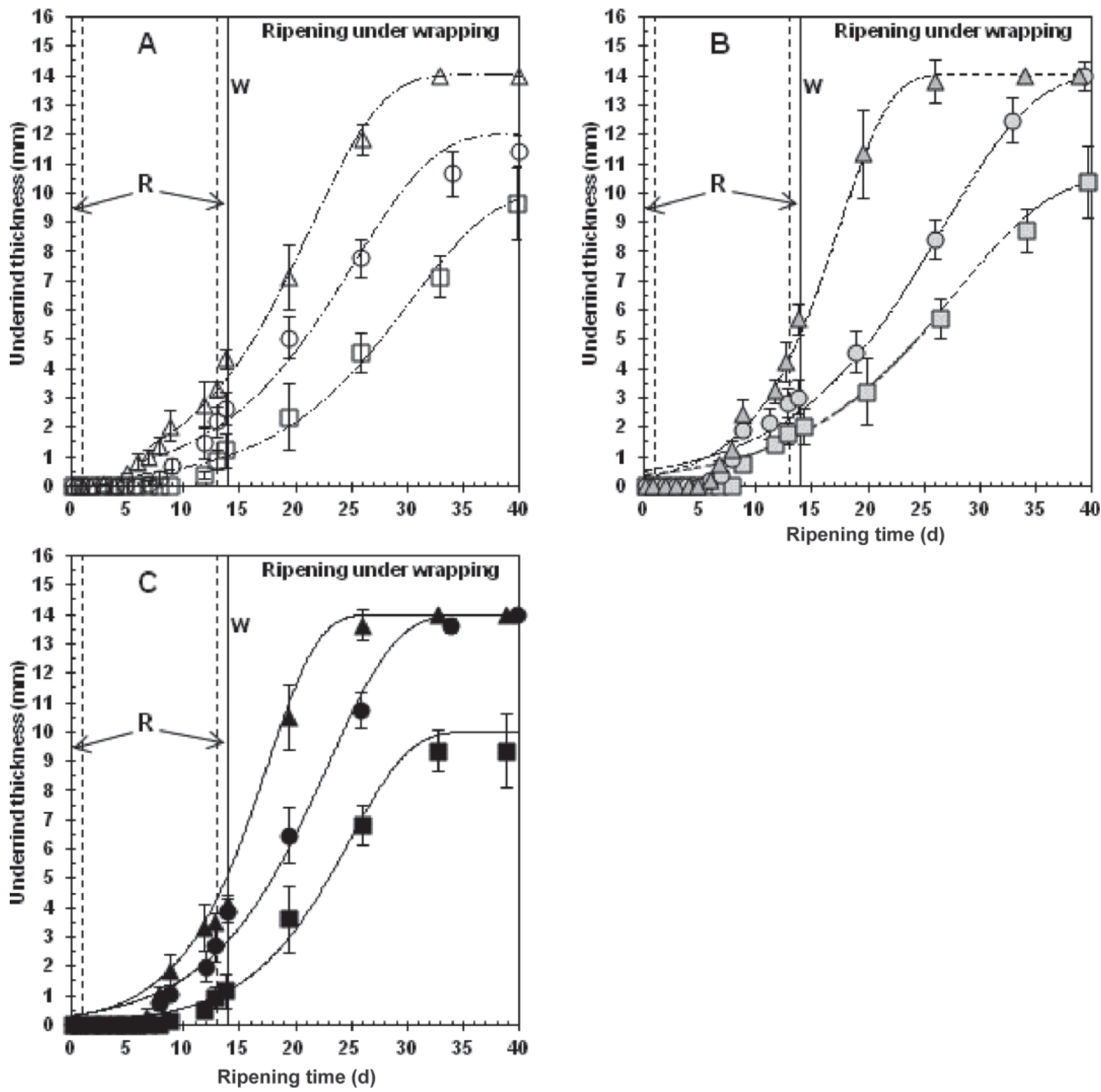

Figure 4. Evolution of underrind thickness $(\mathrm{mm})$, in relation to ripening time for the 9 ripening conditions of temperature and RH and determination of their kinetic descriptors from the Weibull model. The symbols give the experimental points and the line associated with the Weibull model. Each run of the experimental design is represented as follows: $\mathrm{A}=88 \% \mathrm{RH}$ and $8^{\circ} \mathrm{C}$ (open triangles and dashed-dotted line), $12^{\circ} \mathrm{C}$ (open circles and dotted-dashed line), or $16^{\circ} \mathrm{C}$ (open triangles and dashed-dotted line). $\mathrm{B}=92 \% \mathrm{RH}$ and $8^{\circ} \mathrm{C}$ (gray squares and dashed line), $12^{\circ} \mathrm{C}$ (gray circles and dashed line), or $16^{\circ} \mathrm{C}$ (gray triangles and dashed line); $\mathrm{C}=92 \% \mathrm{RH}$ and $8^{\circ} \mathrm{C}$ (solid squares and solid line), $12^{\circ} \mathrm{C}$ (solid circles and solid line), or $16^{\circ} \mathrm{C}$ (solid triangles and solid line). The symbols give the experimental points and the line associated with the Weibull model. $\mathrm{R}=$ surface drying phases carried out under $12^{\circ} \mathrm{C}$ and $85 \% \mathrm{RH}$. W (on $\mathrm{d} 14$ ) = wrapping day. The central point conditions are given as the average of the 5 runs carried out under $12^{\circ} \mathrm{C}$ and $92 \% \mathrm{RH}$ and the error bars represent the standard deviation. 
deviations were weak, and for each microbial or biochemical parameter, it was possible to define 2 kinetic descriptors (the maximal rate and the timing associated with it). Because of these findings, it was possible to turn our attention to the effects of temperature and $\mathrm{RH}$ on the microbial and biochemical characteristics of Camembert-type cheese ripening.

\section{Influences of Ripening Temperature and $\mathrm{RH}$ on Ripening Kinetics}

All statistical tests were carried out using 99\% confidence levels $(P<0.01)$. Some representative 3 -dimensional response surfaces are plotted in Figure 5.

\section{Influences of Ripening Temperature and $\mathbf{R H}$ on Evolutions in K. marxianus (KM)}

The $\mu_{\mathrm{KM}}$ increased from $0.21 \pm 0.06 / \mathrm{d}$ (runs 3 and 4: $8^{\circ} \mathrm{C}, 98 \% \mathrm{RH}$ ) to $0.98 \pm 0.06 / \mathrm{d}$ (run $14: 16^{\circ} \mathrm{C}, 92 \%$ $\mathrm{RH}$ ), and $\mathrm{D}_{\mathrm{KM}}$ increased from $0.038 \pm 0.006 / \mathrm{d}$ (runs 3 and $4: 8^{\circ} \mathrm{C}, 98 \% \mathrm{RH}$ ) to $0.071 \pm 0.006 / \mathrm{d}$ (runs 12 and 13: $16^{\circ} \mathrm{C}, 92 \% \mathrm{RH}$ ), respectively (Table 1 ). The highest values of $\mu_{\mathrm{KM}}$ and $\mathrm{D}_{\mathrm{KM}}$, corresponding to a generation time of $0.7 \mathrm{~d}$ (approximately $17 \mathrm{~h}$ ) and a time of death at $9.9 \mathrm{~d}$, respectively, were obtained at $16^{\circ} \mathrm{C}$ under $98 \%$ $\mathrm{RH}$. The equations describing the effects of temperature on $\mu_{\mathrm{KM}}$ and $\mathrm{D}_{\mathrm{KM}}$ included only temperature with a quadratic term, and the ones describing the effects of temperature on $t_{\mathrm{DKM}}$ included temperature with a linear term (Table 4). The 3-dimensional response surfaces of maximal growth rate $\left(\mu_{\mathrm{KM}}\right.$, per day) and time associated with $\mathrm{D}_{\mathrm{KM}}\left(\mathrm{t}_{\mathrm{DKM}}\right.$, in $\left.\mathrm{d}\right)$ are given in Figures $5 \mathrm{~A}$ and $5 \mathrm{~B}$, respectively. These surfaces, which show an increase only along the temperature axis, confirmed the absence of any influence in the case of $\mathrm{RH}$.

Regardless of the temperature and $\mathrm{RH}$ used throughout ripening, the timing of $\mu_{\mathrm{KM}}$ was $1.50 \pm 0.05 \mathrm{~d}$, and the maximal $K$. marxianus viable cell concentration ranged between $2.3 \times 10^{7}$ and $3.7 \times 10^{7} \mathrm{cfu} / \mathrm{g}$ (results not shown). The ripening conditions had no influence on these 2 descriptors. This can be explained by the following facts: 1) K. marxianus exponential growth begins as soon as the ripening microorganisms are seeded in the milk (Leclercq-Perlat et al., 2004); 2) K. marxianus continues to grow after Camembert cheeses are transferred to the ripening chamber, even if its growth rate is lower than during the cheese-making day; and 3) in this experiment, whatever the run, on d 0 the ripening conditions were the same (first drying phase).

Guéguen and Schmidt (1992) showed that the yeast growth rate was strongly linked to temperature. In our case, the highest growth rate, which was observed at $16^{\circ} \mathrm{C}$, could be explained by the fact that because of the 3 temperatures with which we experimented, $16^{\circ} \mathrm{C}$ was the one closest to the optimal temperature of growth (approximately $25^{\circ} \mathrm{C}$; Barnett et al., 1990). The $K$. marxianus death rate was highly linked to temperature. This is in accordance with the results of Walker and O'Neil (1990); indeed, they observed acceleration in the death of $K$. marxianus with an increase in the culture temperature.

\section{Influence of Ripening Temperature and RH on G. candidum Growth}

The maximal growth rate $\left(\mu_{\mathrm{GC}}\right)$ increased from $0.70 \pm$ $0.07 / \mathrm{d}$ at $8^{\circ} \mathrm{C}$ to approximately $1.7 / \mathrm{d}$ at $16^{\circ} \mathrm{C}$, showing both the influence of temperature and the absence of an effect for RH (Table 1). Temperature had significant quadratic effects on $\mu_{\mathrm{GC}}$, whereas neither temperature nor $\mathrm{RH}$ had an effect on $\mathrm{t}_{\mu \mathrm{GC}}(4.0 \pm 0.2 \mathrm{~d}$; Table 4$)$. Moreover, the maximum values of $\mu_{\mathrm{GC}}$, corresponding to a generation time of $0.38 \mathrm{~d}$ (approximately $9 \mathrm{~h}$ ), were obtained under $16^{\circ} \mathrm{C}$ whatever the $\mathrm{RH}$. The specific growth rate became higher the closer the temperature was to the G. candidum optimum $\left(25^{\circ} \mathrm{C}\right.$; Barnett et al., 1990). Like K. marxianus, G. candidum is not affected by RH higher than $80 \%$ (Guéguen and Schmidt 1992, Lesage-Meessen and Cahagnier 1998). The maximal viable G. candidum concentration was independent of ripening conditions; regardless of the run, it ranged from $2.0 \times 10^{7}$ to $3.9 \times 10^{7} \mathrm{cfu} / \mathrm{g}$ (results not shown).

Temperature affected the growth of both K. marxianus and G. candidum, whereas RH did not influence them. According to Lenoir et al. (1985) and Guéguen and Schmidt (1992), this may be due to the ability of these 2 yeasts to grow equally in a liquid medium and on the surface of cheeses when the RH is higher than $85 \%$. Those authors highlighted that, on the surface of a cheese, the yeast growth is limited by the steric overcrowding of the microorganism layer. This can explain why, in our case, the maximal viable concentrations of $K$. marxianus and G. candidum had the same value regardless of the run. Moreover, Lenoir et al. (1985), Guéguen and Schmidt (1992), and Choisy et al. (2000) showed that these 2 yeasts had no significant strain effects.

\section{Influence of Temperature and $\mathrm{RH}$ on B. aurantiacum Growth}

The $\mu_{\mathrm{BA}}$ increased from approximately $0.25 \pm 0.05$ (at $8^{\circ} \mathrm{C}$ ) to $1.4 \pm 0.2 / \mathrm{d}$ (run $15: 16^{\circ} \mathrm{C}, 98 \% \mathrm{RH}$; Table 1 ). The 3-dimensional response surface of $\mu_{\mathrm{BA}}$ showed a 
A

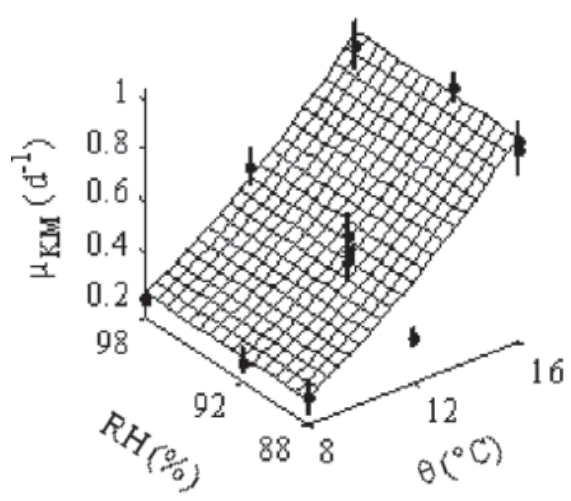

D

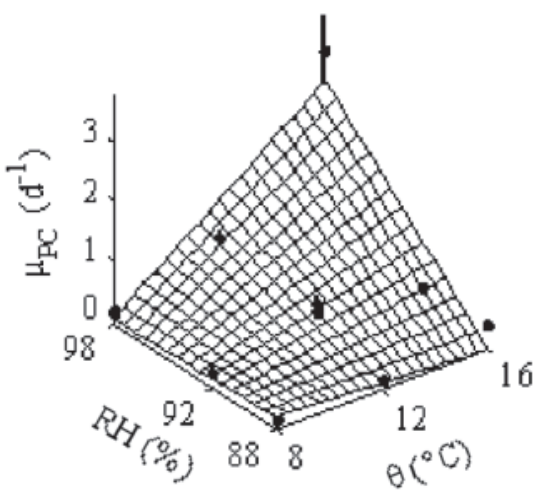

G

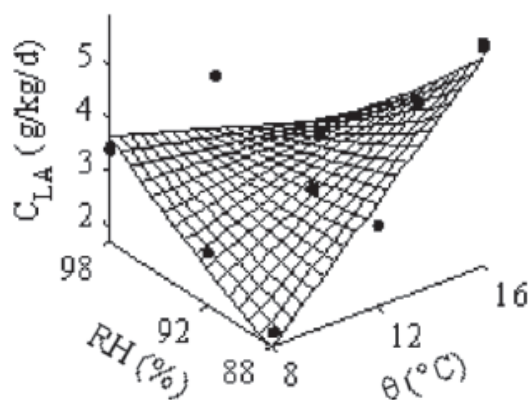

B

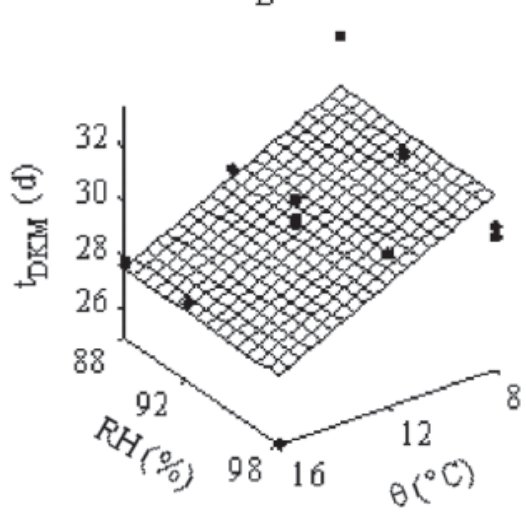

E

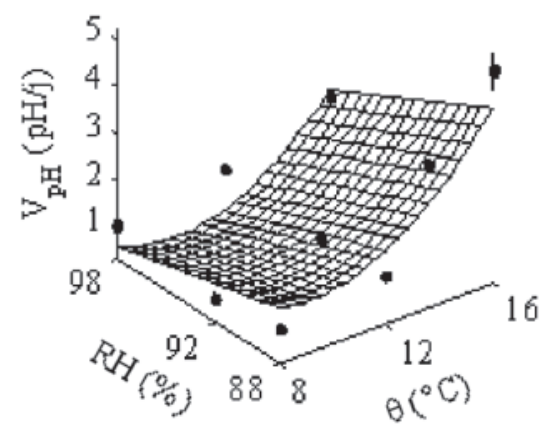

$\mathrm{H}$

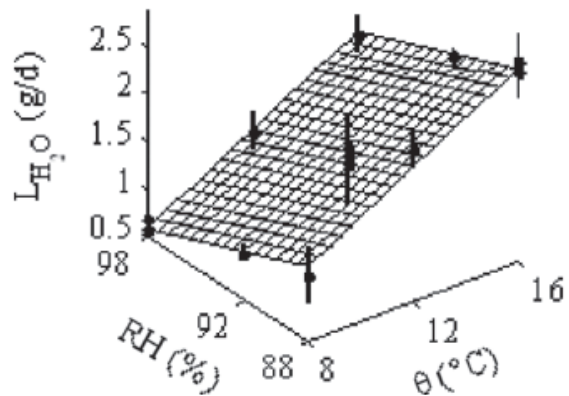

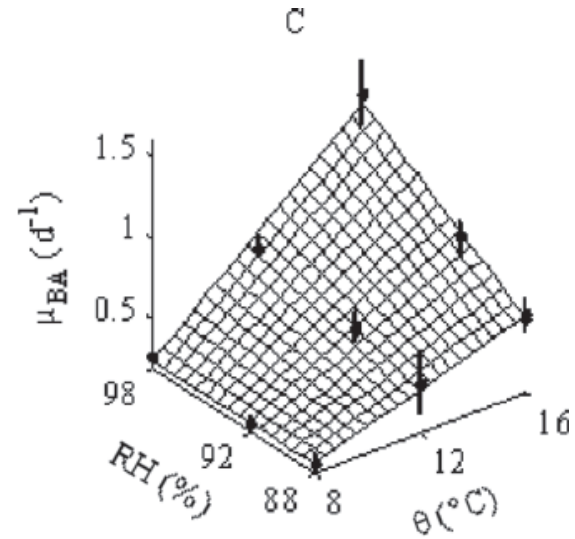

F

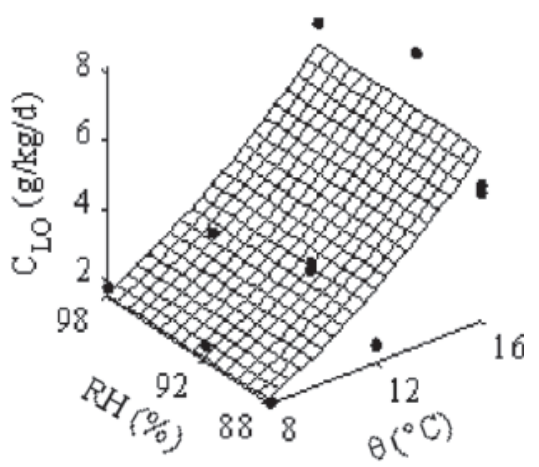

I

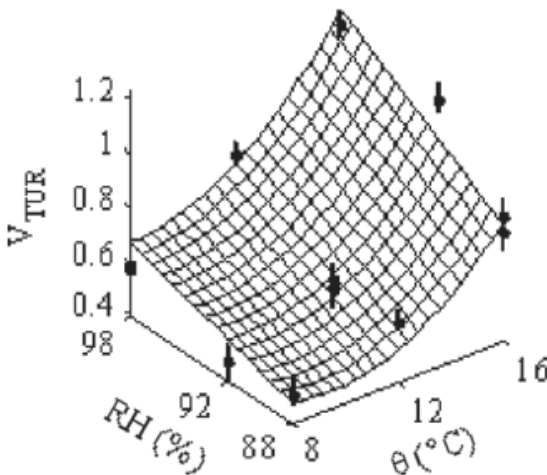

Figure 5. Some representative 3-dimensional response surfaces of dynamic descriptors as functions of temperature $\left(\theta,{ }^{\circ} \mathrm{C}\right)$ and $\mathrm{RH}(\%)$. A) $\mu_{\mathrm{KM}}=$ maximal growth rate of Kluyveromyces marxianus (KM; per day); B) $\mathrm{t}_{\mathrm{DKM}}=$ time associated with the maximal death rate of $K$. marxianus $\left(\mathrm{D}_{\mathrm{KM}}\right.$; in $\left.\left.\mathrm{d}\right) ; \mathrm{C}\right) \mu_{\mathrm{BA}}=$ maximal growth rate of Brevibacterium aurantiacum (BA; per day); D) $\mu_{\mathrm{PC}}=$ maximal sporulation rate of Penicillium camemberti ( $\mathrm{PC}$; per day); $\mathrm{E}) \mathrm{V}_{\mathrm{pH}}=$ maximal rate of $\mathrm{pH}$ increase in the rind; $\mathrm{F}$ ) $\mathrm{C}_{\mathrm{LO}}=$ maximal lactose (LO) consumption rate in the rind ( $\mathrm{g}$ / $\mathrm{kg}$ per day); G) $\mathrm{C}_{\mathrm{LA}}=$ maximal lactate (LA) consumption rate in the rind ( $\mathrm{g} / \mathrm{kg}$ per day); $\left.\mathrm{H}\right) \mathrm{L}_{\mathrm{H} 2 \mathrm{O}}=$ cheese mass water loss rate (g/d); I) $\mathrm{V}_{\mathrm{UR}}$ $=$ maximal rate of increase of underrind (UR) thickness $(\mathrm{mm} / \mathrm{d})$. Error bars represent the standard deviation.

strong increase in $\mu_{\mathrm{BA}}$ for a combined increase in temperature and RH (Figure 5C). The effect of 1 factor was higher when the other factor had a higher value, denoting a positive interaction. Moreover, the equation associated with this figure confirmed that temperature and RH had significant linear effects and an interactive effect on $\mu_{\mathrm{BA}}$ (Table 4 ). At $8^{\circ} \mathrm{C}$, regardless of the $\mathrm{RH}$, $\mu_{\mathrm{BA}}$ remained constant, whereas at $16^{\circ} \mathrm{C}, \mu_{\mathrm{BA}}$ was 2 times higher when RH increased from 88 to $98 \%$ (Table 1). Temperature had a significant influence (linear and 
Table 4. Best-fit equations for the effects of temperature $\left(\theta,{ }^{\circ} \mathrm{C}\right)$ and relative humidity $(\mathrm{RH}, \%)$ on microbial dynamic descriptors during Camembert-type cheese ripening ${ }^{1}$

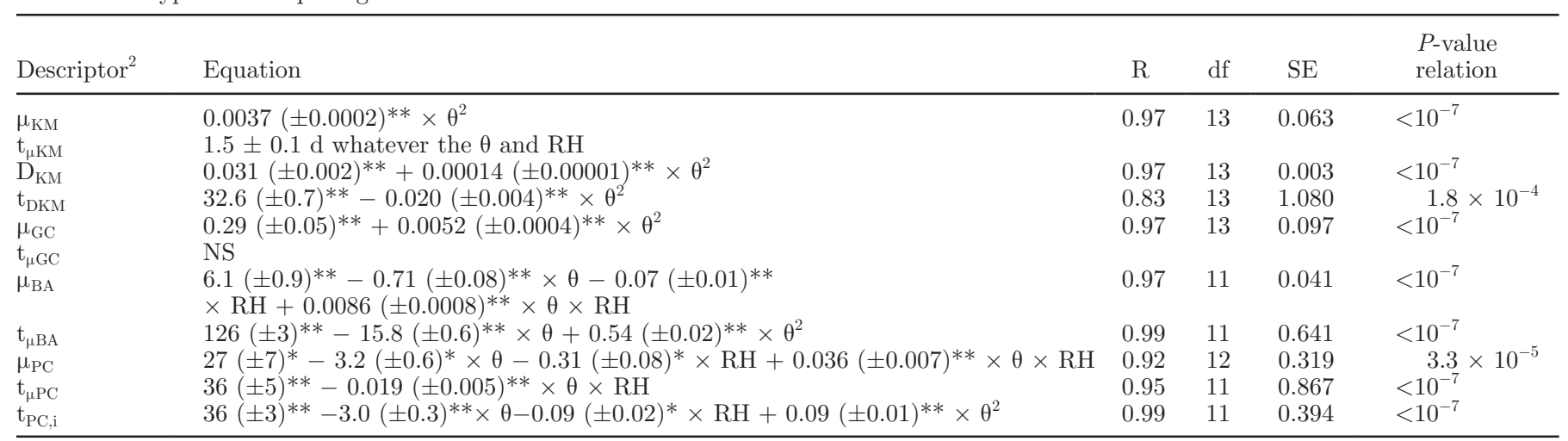

${ }^{1}$ All factors of the equations for temperature and $\mathrm{RH}$ are given. $\mathrm{R}=$ coefficient of determination.

${ }^{2}$ Variables: $\mu=$ maximum growth rate (per day), and $t_{\mu}=$ day for which $\mu$ is obtained (in $d$ ); $D_{\text {KM }}=$ maximum death rate (per day) of Kluyveromyces marxianus $(\mathrm{KM})$, and $\mathrm{t}_{\mathrm{DKM}}=$ day for which $\mathrm{D}_{\mathrm{KM}}$ is obtained (in $\left.\mathrm{d}\right)$; $\mathrm{t}_{\mathrm{PC}, \mathrm{i}}=$ day on which the first mycelia of Penicillium camemberti $(\mathrm{PC}$ ) were observed (in d); $\mathrm{GC}=$ Geotrichum candidum; $\mathrm{BA}=$ Brevibacterium aurantiacum.

${ }^{*} P<0.01 ;{ }^{*} P<0.001$.

quadratic terms) on $\mathrm{t}_{\mu \mathrm{BA}}$ (Table 4). The higher the temperature, the lower the $\mathrm{t}_{\mu \mathrm{BA}}$.

Brevibacterium aurantiacum grows better when the temperature is close to its optimal growth temperature $\left(25^{\circ} \mathrm{C}\right.$ ) and when the $\mathrm{RH}$ is close to $98 \%$ (Bergère and Tourneur, 1992; Bonaïti et al., 2004). Indeed, B. aurantiacum is greatly affected when the RH is lower than 90\% (Reps, 1993). In our experiment, at $8^{\circ} \mathrm{C}$ under $88 \%$ $\mathrm{RH}$, its growth was restricted, and from d 0 to 40 , the concentration increase was less than $80 \mathrm{cfu} / \mathrm{g}$, whereas under RH $98 \%$, the growth of B. aurantiacum was higher and the concentration increase reached almost $10^{3} \mathrm{cfu} / \mathrm{g}$. At $16^{\circ} \mathrm{C}$, under $88 \% \mathrm{RH}$, B. aurantiacum grew better, and the concentration increase from $\mathrm{d} 0$ to 40 reached $10^{4} \mathrm{cfu} / \mathrm{g}$, whereas under $98 \% \mathrm{RH}$, its growth was highest and the concentration increase reached more than $10^{5} \mathrm{cfu} / \mathrm{g}$. Moreover, under $16^{\circ} \mathrm{C}$ and $98 \%$, the cheese rind had a dark brown color after d 20, which is considered a flaw for Camembert-type cheese. Even though the influence of temperature alone was important, our findings highlighted the role of the interaction between temperature and $\mathrm{RH}$ on $B$. aurantiacum growth. Moreover, Bergère and Tourneur (1992) and Reps (1993) showed that no significant strain dependence exists for strains of the Brevibacterium linens group, which includes $B$. aurantiacum.

\section{Influence of Ripening Temperature and $\mathrm{RH}$ on P. camemberti Sporulation}

The $\mu_{\mathrm{PC}}$ increased from approximately 0.04 (run 1: $\left.8^{\circ} \mathrm{C}, 88 \% \mathrm{RH}\right)$ to $3.2 \pm 0.6 / \mathrm{d}\left(\right.$ run $15: 16^{\circ} \mathrm{C}, 98 \% \mathrm{RH}$; Table 1). After wrapping, P. camemberti spore concentrations remained constant regardless of the ripening conditions. The 3-dimensional response surface of the $\mu_{\mathrm{PC}}$ showed a strong increase when the interaction of temperature and $\mathrm{RH}$ was accounted for (Figure 5D). The effect of 1 factor was higher when the other factor had a higher value, denoting a positive interaction. The equation associated with $\mu_{\mathrm{PC}}$ highlighted the temperature and $\mathrm{RH}$ (linear and interactive terms; Table $4)$. The time associated with $\mu_{\mathrm{PC}}$ was modeled by an interactive term for $\theta$ and $\mathrm{RH}$ (Table 4).

For some other Penicillium strains, Mislivec et al. (1975) found that 1) the spore germination and sporulation are controlled by both temperature and $\mathrm{RH}, 2$ ) these 2 conditions are interrelated, and 3) this interrelationship differs for each strain. Regardless of the temperature under $88 \% \mathrm{RH}$, and regardless of the $\mathrm{RH}$ at $8^{\circ} \mathrm{C}, \mu_{\mathrm{PC}}$ values were very low. The increase in spore concentration from d 5 to 14 was lower than $0.7 \log$. At 12 or $16^{\circ} \mathrm{C}$ under 92 or $98 \% \mathrm{RH}, \mu_{\mathrm{PC}}$ increased (Table $1)$, and $P$. camemberti maximal spore concentration remained constant (approximately $10^{5}$ spores/g) after d 14 . At $16^{\circ} \mathrm{C}$ under $98 \% \mathrm{RH}, \mu_{\mathrm{PC}}$ corresponding to a generation time of $5.25 \mathrm{~h}$ was the highest, reaching 1.6 $\times 10^{6}$ spores/g. Indeed, it was 16 times higher than the concentrations observed in the other runs (results not shown). This reflects a significant sporulation of P. camemberti. Moreover, at $16^{\circ} \mathrm{C}$, the appearance of the rind was no longer suitable because mycelia were damaged.

\section{Influence of Temperature and RH on Evolutions in Rind $\mathrm{pH}$ and Carbon Substrates}

$\boldsymbol{p H}$ of the Rind. The evolutions of $\mathrm{pH}$ in the cheese rind made it possible to separate the runs into 
Table 5. Best-fit equations for the effects of temperature $\left(\theta,{ }^{\circ} \mathrm{C}\right)$ and relative humidity $(\mathrm{RH}, \%)$ on physicochemical and biological kinetic descriptors during Camembert-type cheese ripening ${ }^{1}$

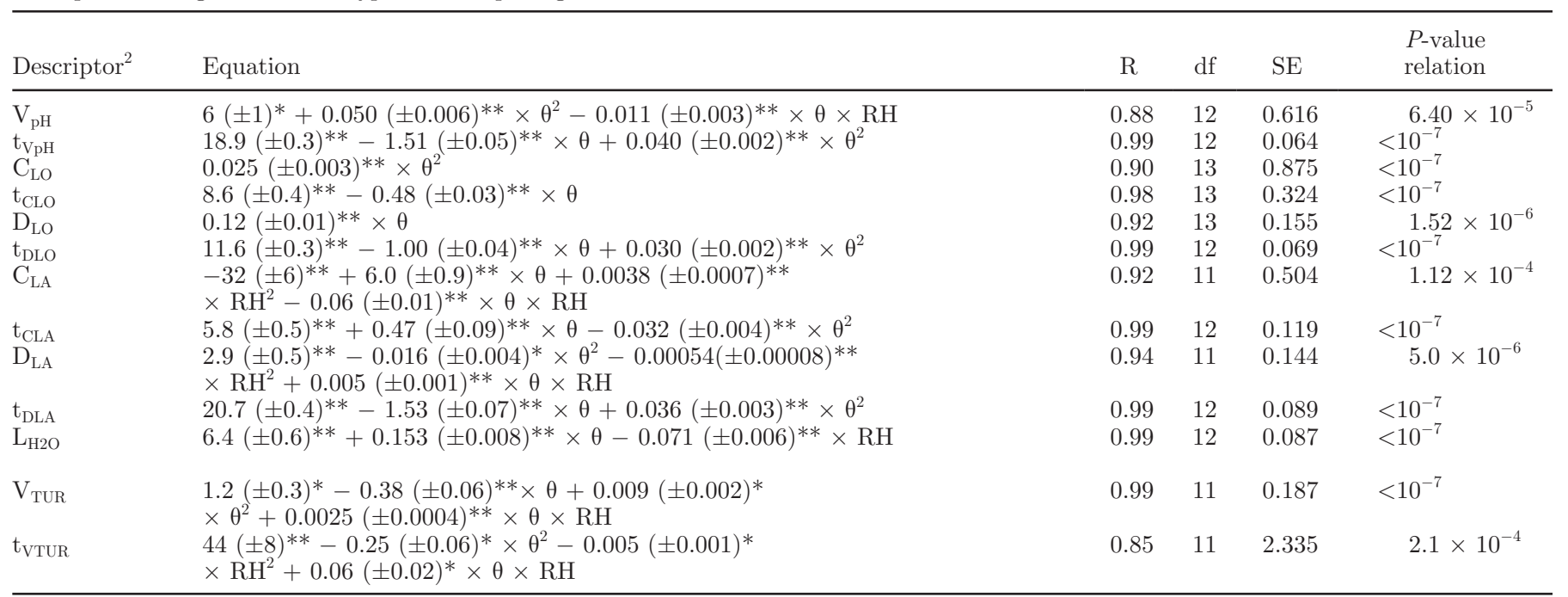

${ }^{1}$ All factors of the equations for temperature and $\mathrm{RH}$ are given. $\mathrm{R}=$ coefficient of determination.

${ }^{2}$ Variables: $V_{\mathrm{X}}=$ maximal rate of increase of descriptor $\mathrm{X}$ (unit/d), and $\mathrm{t}_{\mathrm{VX}}=$ time for which the maximal rate of increase $\mathrm{V}$ is obtained $(\mathrm{d}$ ), where $\mathrm{X}=\mathrm{pH}$ for $\mathrm{pH}$ and TUR for cheese underrind thickness; $\mathrm{C}_{\mathrm{LO}}=$ lactose maximal consumption rate in the rind ( $\mathrm{g} / \mathrm{kg}$ per day), and $\mathrm{t}_{\mathrm{CLO}}$ $=$ time for which $\mathrm{C}_{\mathrm{LO}}$ is obtained $(\mathrm{d}) ; \mathrm{D}_{\mathrm{LO}}=$ lactose maximal rate of decrease in the core $\left(\mathrm{g} / \mathrm{kg}\right.$ per day), and $\mathrm{t}_{\mathrm{DLO}}=$ time for which $\mathrm{D}_{\mathrm{LO}}$ is obtained (d); $\mathrm{C}_{\mathrm{LA}}=$ lactate maximal consumption rate in the rind $\left(\mathrm{g} / \mathrm{kg}\right.$ per day), and $\mathrm{t}_{\mathrm{CLA}}=$ time for which $\mathrm{C}_{\mathrm{LA}}$ is obtained $(\mathrm{d}) ; \mathrm{D}_{\mathrm{LA}}=$ lactate maximal rate of decrease in the core $\left(\mathrm{g} / \mathrm{kg}\right.$ per day), and $\mathrm{t}_{\mathrm{DLA}}=$ time for which $\mathrm{D}_{\mathrm{LA}}$ is obtained $(\mathrm{d})$.

${ }^{*} P<0.01 ; * * P<0.001$.

3 groups in terms of temperature (Table 2, Figure 2). The response surface of the maximal increase rate of $\mathrm{pH}$ in the rind $\left(\mathrm{V}_{\mathrm{pH}}\right.$, in units/d) showed that temperature had a strong, positive effect on $\mathrm{V}_{\mathrm{pH}}$, whereas $\mathrm{RH}$ had a weak, negative effect (Figure 5E). The equation for $\mathrm{V}_{\mathrm{pH}}$ associated with this surface was linked to temperature (quadratic term) and its interactive term with $\mathrm{RH}$, whereas $t_{\mathrm{VpH}}$ was linked only to temperature (individual and quadratic terms) (Table 5). The correlation between $\mathrm{pH}$ and the ripening conditions under study had a high standard error value (SE close to 0.6$)$.

It is generally agreed that the $\mathrm{pH}$ of the rind depends on lactate consumption and alkaline product accumulation. Indeed, Gori et al. (2007) showed that during their growth, most cheese yeasts produce ammonia. Leclercq-Perlat et al. (2004) showed that lactate consumption was related to $K$. marxianus when any lactose was available in the rind, as well as to $G$. candidum growth and P. camemberti mycelium development. Therefore, both K. marxianus and G. candidum growth descriptors were dependent on temperature, whereas $P$. camemberti mycelium development was related to the interaction of temperature and $\mathrm{RH}$. This could be explained by the influence of $\mathrm{RH}$ on $\mathrm{V}_{\mathrm{pH}}$. Indeed, the lower the $\mathrm{RH}$, the drier the cheese and the more restricted the aqueous phase of the cheese.
Lactose Changes. The maximal $\mathrm{C}_{\mathrm{LO}}$ increased from 1.59 (run $1: 8^{\circ} \mathrm{C}, 98 \% \mathrm{RH}$ ) to $8.1 \mathrm{~g} / \mathrm{kg}$ per day (run 14: $16^{\circ} \mathrm{C}, 92 \% \mathrm{RH}$; Table 2, Figure 3A). The response surface of $\mathrm{C}_{\mathrm{LO}}$ in the rind showed an increase only along the temperature axis (Figure $5 \mathrm{~F}$ ), confirming the importance of temperature for this descriptor. The $\mathrm{C}_{\mathrm{LO}}$ and $t_{\text {CLO }}$ were related to temperature (quadratic and linear terms, respectively; Table 5). Regardless of the run, the decrease in lactose began on d 0 and took place during $K$. marxianus growth, confirming previous findings by Leclercq-Perlat et al. (2004). Among the ripening microorganisms, in the rind only $K$. marxianus metabolizes lactose into alcohols, water, and $\mathrm{CO}_{2}$. Its growth was dependent only on temperature, explaining the dependence of lactose consumption on temperature in the rind.

In the core, the $\mathrm{D}_{\mathrm{LO}}$ (in $\mathrm{g} / \mathrm{kg}$ per day) and its associated timing ( $t_{\mathrm{DLO}}$, in $\mathrm{d}$ ) were modeled by a function of temperature (linear term) for both descriptors plus a quadratic term for $t_{\text {DLO }}$ (Table 5). The lactose concentration in the core is mainly linked to the one in the rind because of the importance of lactose diffusion from the core to the rind (Leclercq-Perlat et al., 2004). A higher temperature favors a higher activity of $K$. marxianus (Table 4), involving faster lactose consumption in the rind (Figure 3). In consequence, a concentration gradient of lactose appears between the core and the 
rind, inducing lactose diffusion toward the rind (Riahi et al., 2007) and a decrease in the core. In addition, higher temperatures may strongly increase the diffusion coefficient of lactose.

Lactate Changes. The $\mathrm{C}_{\mathrm{LA}}$ (in $\mathrm{g} / \mathrm{kg}$ per day) in the rind increased from 1.97 (run 1: $8^{\circ} \mathrm{C}, 88 \% \mathrm{RH}$ ) to a maximum of $5.83 \mathrm{~g} / \mathrm{kg}$ per day (runs 12 and $13: 16^{\circ} \mathrm{C}$, $88 \% \mathrm{RH}$ ) and then decreased to $2.2 \mathrm{~g} / \mathrm{kg}$ per day (run 15: $16^{\circ} \mathrm{C}, 98 \% \mathrm{RH}$; Table 2, Figure $3 \mathrm{~A}$ ). In the given range, for low temperatures, the $\mathrm{RH}$ had a positive effect on the maximum $\mathrm{C}_{\mathrm{LA}}$, but this effect was reversed in the case of high temperatures (Figure 5G). Similarly, under low $\mathrm{RH}$, the increase in temperature caused the $\mathrm{C}_{\mathrm{LA}}$ to increase, but it had almost no effect under high $\mathrm{RH}$. This behavior denoted a strong negative interaction between temperature and $\mathrm{RH}$.

The $\mathrm{C}_{\mathrm{LA}}$ was related to temperature (linear term), $\mathrm{RH}$ (quadratic term), and the interaction between temperature and $\mathrm{RH}$ (interactive term), whereas $\mathrm{t}_{\mathrm{CLA}}$ depended only on the temperature (individual and quadratic terms; Table 5). The day when the end of postacidification phase occurred also depended on the temperature: it began on d 3 for runs carried out at $16^{\circ} \mathrm{C}$ and began on $\mathrm{d} 6$ for those carried out at $8^{\circ} \mathrm{C}$ (Figure 3B).

In the rind, all ripening microorganisms consume lactate (Choisy et al., 2000; Leclercq-Perlat et al., 2004). Kluyveromyces marxianus uses lactate only when the lactose concentration becomes negligible. The decrease in lactate concentration is related to G. candidum growth and to $P$. camemberti mycelium development (visually observed), mainly influenced by temperature (Choisy et al., 2000). According to the authors, water activity depends on cheese humidity (determined by $\mathrm{DM}$ ), salting level, and the $\mathrm{RH}$ used in the ripening chamber. In this study, only RH varied. However, when $\mathrm{RH}$ is lower than $90 \%$, the water evaporation from the rind to the atmosphere becomes higher, causing a significant drying of the rind (Ramet, 2000). This involves a diminution of enzymatic activities and therefore a decrease in $\mathrm{C}_{\mathrm{LA}}$. This explains why $\mathrm{C}_{\mathrm{LA}}$ is dependent on RH (Figure 5G).

In the core, the maximal $\mathrm{D}_{\mathrm{LA}}$ was related to temperature and RH (quadratic terms), and their interaction, whereas $t_{\text {DLA }}$ was affected only by temperature (individual and quadratic terms).

The lactate concentration in the core is mainly related to the one of the rind. Indeed, Leclercq-Perlat et al. (2004) showed the importance of the lactate diffusion phenomenon from the core to the rind. A higher temperature favors a higher activity of lactate consumption by the ripening microorganisms (Table 4). Similar to lactose, a concentration gradient of lactate appears be- tween the core and the rind, inducing lactate diffusion toward the rind (Riahi et al., 2007). This may explain the correlation between lactate decreasing in the core and the ripening conditions under study.

\section{Influence of Temperature and $\mathrm{RH}$ on Cheese Water Mass Losses}

The $\mathrm{L}_{\mathrm{H} 2 \mathrm{O}}$ increased from $0.6 \mathrm{~g} / \mathrm{d}$ (runs 3 and $4: 8^{\circ} \mathrm{C}$, $98 \% \mathrm{RH}$ ) to $2.6 \mathrm{~g} / \mathrm{d}$ (runs 12 and $13: 16^{\circ} \mathrm{C}, 88 \%$; Table $3)$. In the given range, temperature had a positive effect and $\mathrm{RH}$ had a negative effect on $\mathrm{L}_{\mathrm{H} 2 \mathrm{O}}$ (Figure $5 \mathrm{H}$, Table $5)$. Water constitutes the main part of weight loss, and it was both vaporized from the cheese surface to the atmosphere and diffused from the cheese core to the surface (Simal et al., 2001).

The sole effect of $\mathrm{RH}$ on $\mathrm{L}_{\mathrm{H} 2 \mathrm{O}}$ was previously shown for a smear cheese (Bonaïti et al., 2004). In our case, the $\mathrm{L}_{\mathrm{H} 2 \mathrm{O}}$ was the highest under $88 \% \mathrm{RH}$ : approximately $30 \%$ of the initial cheese mass was lost. However, temperature and $\mathrm{RH}$ alone do not explain cheese weight loss; a combination of other environmental conditions and cheese composition can influence the drying rate (Bonaïti et al., 2004).

\section{Influence of Ripening Temperature and RH on the Evolution of Underrind Thickness}

Temperature had an effect on the time when the underrind became visible $\left(\mathrm{t}_{\mathrm{UR}, \mathrm{i}}\right.$, in $\left.\mathrm{d}\right)$. This happened at $9.0,7.0$, and $5.0 \mathrm{~d}$ and 8,12 , and $16^{\circ} \mathrm{C}$, respectively (results not shown). The $\mathrm{V}_{\text {TUR }}$ (in $\mathrm{mm} / \mathrm{d}$ ) increased from approximately $0.55 \mathrm{~mm} / \mathrm{d}$ at $8^{\circ} \mathrm{C}$ to approximately $1.15 \mathrm{~mm} / \mathrm{d}$ at $16^{\circ} \mathrm{C}$ under 92 or $98 \% \mathrm{RH}$ (Table 3 ). Its response surface showed a strong increase of $\mathrm{V}_{\mathrm{TUR}}$ for a combined increase in temperature and RH (Figure 5I). The effect of 1 factor was higher when the other factor had a higher value, denoting a positive interaction. The $\mathrm{V}_{\text {TUR }}$ was related to temperature (individual and quadratic terms) and the interaction between temperature and $\mathrm{RH}$ (interactive term). Its associated timing was dependent on temperature (quadratic term) and RH (quadratic term) as well as on their interaction (Table $5)$.

The underrind thickness provides information on the overall proteolysis and lipolysis of the cheeses (Bonaiti et al., 2004). The underrind begins to grow when proteins and lipids begin to be used by ripening microorganisms near the surface (Leclercq-Perlat et al., 2006, 2007). According to Lenoir et al. (1985) and Leclercq-Perlat et al. (2007), this is mainly related to temperature: the higher the temperature, the sooner the metabolism of proteins and lipids by microorganisms occurs. In our 
case, the underrind of cheeses ripened under lower $\mathrm{RH}$ $(<90 \%)$ dried out and grew slower than those under the other ripening conditions. On the contrary, under $98 \% \mathrm{RH}$ and $16^{\circ} \mathrm{C}$, the underrind increased quickly, and on d 14 its thickness reached more than $6 \mathrm{~mm}$ per face (Figure 4), whereas on d 40, the cheeses were completely runny.

\section{CONCLUSIONS}

Whatever the temperature, a $\mathrm{RH}$ of $88 \%$ affected microorganism growth, the increase in $\mathrm{pH}$, carbon substrate consumption, and the thickening of the underrind throughout cheese ripening. Whatever the $\mathrm{RH}$, a temperature of $16^{\circ} \mathrm{C}$ induced an acceleration of the cheese-ripening process. Indeed, microorganism growth and biochemical modifications began earlier at this temperature than at the other temperatures. In fact, to attain an optimum between microbiological and biochemical characteristics, the best ripening conditions were $13^{\circ} \mathrm{C}$ and $94 \% \mathrm{RH}$. This study provides a means for achieving a better and more rational control of the ripening process in the case of Camembert and Camembert-like cheeses.

\section{ACKNOWLEDGMENTS}

This work was supported by the French Research Ministry through a Programme National de la Recherche Agronomique (PNRA) contract. We are deeply grateful to N. Perrot (UMR GMPA, Thiverval-Grignon, France) as project coordinator. We thank F. Lecornué (UMR GMPA) for his help with the cheese making and T. Cattenoz (UMR GMPA) for his technical and sensor monitoring assistance. We also thank S. Tanis-Plant (INRA) for her editorial advice in English.

\section{REFERENCES}

Barnett, J. A., R. W. Payne, and D. Yarrow. 1990. A Guide to Identifying and Classifying Yeasts. 4th ed. Cambridge University Press, Cambridge, UK.

Bergère, J. L., and C. Tourneur. 1992. The smear of the cheese surface. Pages 127-163 in Les Groupes Microbiens d'Intérêt Laitier. J. Hermier, J. Lenoir, and W. Weber, ed. Centre d'Enseignement Professionnel des Industries Laitières (CEPIL), Paris, France.

Bonaïti, C., M.-N. Leclercq-Perlat, E. Latrille, and G. Corrieu. 2004. Deacidification by Debaryomyces hansenii of smear soft cheeses ripened under controlled conditions: Relative humidity and temperature influences. J. Dairy Sci. 87:3976-3988.

Callon, C., D. Picque, G. Corrieu, and M. C. Montel. 2011. Ripening conditions: A tool for the control of Listeria monocytogenes in uncooked pressed type cheese. Food Contr. 22:1911-1919.

Choisy, C., M. Desmazeaud, J. C. Gripon, G. Lamberet, and J. Lenoir. 2000. The biochemistry of ripening. Pages $82-151$ in Cheesemaking: From Science to Quality Assurance. A. Eck and J. C. Gillis, ed. Lavoisier Publishing, Paris, France.
Cohen, J. 1992. A power primer. Psychol. Bull. 112:155-159.

Gori, K., H. D. Mortensen, N. Arneborg, and L. Jespersen. 2007. Ammonia production and its possible role as mediator of communication for Debaryomyces hansenii and other cheese-relevant yeast species. J. Dairy Sci. 90:5032-5041.

Gripon, A. 1993. Mould-ripened cheeses. Pages 111-136 in Cheese: Chemistry, Physics and Microbiology. Vol. 2. P. F. Fox, ed. Chapman and Hall, London, UK.

Guéguen, M., and J. L. Schmidt. 1992. Levures et Geotrichum candidum. Pages 165-196 in Les Groupes Microbiens d'Intérêt Laitier. J. Hermier, J. Lenoir, and W. Weber, ed. Centre d'Enseignement Professionnel des Industries Laitières (CEPIL), Paris, France.

Hardy, J., J. Scher, H. E. Spinnler, E. Guichard, and J. C. Gripon. 2000. Physical and sensory properties of cheese. Pages 447-473 in Cheesemaking: From Science to Quality Assurance. A. Eck and J. C. Gillis, ed. Intercept Limited, Andover, UK.

Hemme, D., and J. Richard. 1986. Utilization of L-methionine and production of methanethiol by bacteria isolated from raw milk Camembert cheese. Lait 66:135-142.

Leclercq-Perlat, M.-N., F. Buono, H.-E. D. Lambert, H. E. Spinnler, and G. Corrieu. 2004. Controlled production of Camembert-type cheeses: Part I. Microbiological and physicochemical evolutions. J. Dairy Res. 71:346-354.

Leclercq-Perlat, M.-N., G. Corrieu, and H.-E. Spinnler. 2007. Controlled production of Camembert-type cheeses: Part III. Free fatty acid evolutions. J. Dairy Res. 74:218-225.

Leclercq-Perlat, M.-N., D. Picque, H. Riahi, and G. Corrieu. 2006. Microbiological and biochemical aspects of Camembert-type cheeses depend on atmospheric composition in the ripening chamber. J. Dairy Sci. 89:3260-3273.

Lenoir, J., G. Lamberet, J. L. Schmidt, and C. Tourneur. 1985. La maîtrise du bioréacteur Fromage. Biofutur 41:23-50.

Lesage-Meessen, L., and B. Cahagnier. 1998. Mécanismes d'adaptation des micromycètes aux activités de l'eau réduite. Pages 19-35 in Moisissures des aliments peu hydratés. B. Cahagnier, ed. Sciences et Techniques Agro-Alimentaires, Lavoisier Tec \& Doc, Paris, France.

Malcata, F. X., A. M. P. Gomes, and M. L. da Costa. 1995. 'Probiotic' goat cheese: Effect of ripening temperature and relative humidity on proteolysis and lipolysis. J. Dairy Sci. 78(Suppl. 1):99. (Abstr.)

Mirade, P.-S., T. Rougier, A. Kondjoyan, J.-D. Daudin, D. Picque, and G. Corrieu. 2004. Caractérisation expérimentale de l'aéraulique d'un hâloir de fromagerie et des échanges air-produit. Lait $84: 483-500$.

Mislivec, P. B., T. C. Dieter, and V. R. Bruce. 1975. Effect of temperature and relative humidity on spore germination of mycotoxic species of Aspergillus and Penicillium. Mycologia 67:1187-1189.

Nunez, M., A. M. Guillen, M. A. Rodriguez-Marin, A. M. Marcilla, P. Gaya, and M. Medina. 1991. Accelerated ripening of ewes' milk Manchego cheese: The effect of neutral proteinases. J. Dairy Sci. 74:4108-4118.

Picque, D., M.-N. Leclercq-Perlat, and G. Corrieu. 2006. Effects of atmospheric composition on respiratory behavior, weight loss, and appearance of Camembert-type cheeses during chamber ripening. J. Dairy Sci. 89:3250-3259.

Ramet, J. P. 2000. Comparing ripening technology of the various types of cheese. Pages 418-446 in Cheesemaking: From Science to Quality Assurance. A. Eck and J. C. Gillis, ed. Lavoisier Publishing, Paris, France.

Reps, A. 1993. Bacterial Surface-ripened cheeses. Pages 137-172 in Cheese: Chemistry, Physics and Microbiology. Vol. 1: General Aspects. 2nd ed. P. F. Fox, ed. Chapman and Hall, London, UK.

Riahi, M.H., C. Trelea, D. Picque, M.-N. Leclercq-Perlat, A. Hélias, and G. Corrieu. 2007. A model describing Debaryomyces hansenii growth and substrate consumption during a smear soft cheese deacidification and ripening. J. Dairy Sci. 90:2525-2537.

Schepers, A. W., J. Thibault, and C. Lacroix. 2000. Comparison of simple neural networks and nonlinear regression models for de- 
scriptive modelling of Lactobacillus helveticus growth in $\mathrm{pH}$ controlled batch cultures. Enzyme Microb. Technol. 26:431-445.

Sihufe, G. A., S. E. Zorilla, D. J. Mercanti, M. C. Perotti, C. A. Zalazar, and A. C. Rubiolo. 2007. The influence of ripening temperature and sampling site on the lipolysis in Reggianito Argentino Cheese. Food Res. Int. 40:1220-1226.

Sihufe, G. A., S. E. Zorilla, M. C. Perotti, I. V. Wolf, C. A. Zalazar, N. G. Sabbag, and A. C. Rubiolo. 2010a. Acceleration of cheese ripening at elevated temperature. An estimation of the optimal ripening time of a traditional Argentinean hard cheese. Food Chem. 119:101-107.

Sihufe, G. A., S. E. Zorilla, and A. C. Rubiolo. 2010b. The influence of ripening temperature and sampling site on the proteolysis in Reggianito Argentino cheese. Food Sci. Technol. 43:247-253.

Simal, S., E. S. Sanchez, J. Bon, A. Femenia, and C. Rossello. 2001. Water and salt diffusion during cheese ripening: Effect of the ex- ternal and internal resistances to mass transfer. J. Food Eng. $48: 269-275$

van den Tempel, T., and M. Jakobsen. 2000. The technological characteristics of Debaryomyces hansenii and Yarrowia lipolytica and their potential as starter cultures for production of Danablu. Int. Dairy J. 10:263-270.

Von Weissenfluh, A., and Z. Puhan. 1987. The effect of environmental conditions in the ripening room on the growth of Penicillium camemberti and the quality of Camembert cheese. Schweiz. Milchwirtsch. Forsch. 16:37-44.

Walker, G. M., and J. D. O'Neil. 1990. Morphological and metabolic changes in the yeast Kluyveromyces marxianus var. Marxianus NRRLY2415 during fermentation of lactose. J. Chem. Technol Biotechnol. 49:75-89. 